\title{
Tracking Improvement in Simulated Marine Biogeochemistry Between CMIP5 and CMIP6
}

\author{
Roland Séférian ${ }^{1}$ (D) - Sarah Berthet ${ }^{1}$ (D) - Andrew Yool $^{2}$ (D) Julien Palmiéri ${ }^{2}$ (D) $\cdot$ Laurent Bopp $^{3}$ (D) \\ Alessandro Tagliabue $^{4}$ (D) $\cdot$ Lester Kwiatkowski $^{5}$ (D) - Olivier Aumont $^{5}$ (D) . James Christian ${ }^{6}$ (D) John Dunne ${ }^{7}$ (D) . $^{2}$ \\ Marion Gehlen ${ }^{8}$ (D) - Tatiana llyina ${ }^{9}$ (D) - Jasmin G. John ${ }^{7}$ (D) . Hongmei Li $^{9}$ (D) - Matthew C. Long ${ }^{10}$ (D) - Jessica Y. Luo ${ }^{7}$ (D) \\ Hideyuki Nakano ${ }^{11}$ (D) Anastasia Romanou ${ }^{12}$ (D) - Jörg Schwinger ${ }^{13}$ (D) Charles Stock $^{7}$ (D) Yeray Santana-Falcón ${ }^{1}$ (D)

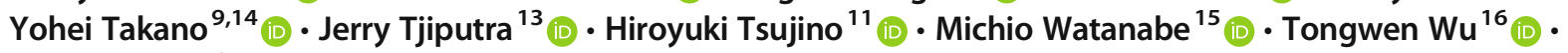 \\ Fanghua $\mathrm{Wu}^{16}$ (D) Akitomo Yamamoto ${ }^{15}$ (D)
}

Published online: 18 August 2020

(C) The Author(s) 2020

\section{Abstract}

Purpose of Review The changes or updates in ocean biogeochemistry component have been mapped between CMIP5 and CMIP6 model versions, and an assessment made of how far these have led to improvements in the simulated mean state of marine biogeochemical models within the current generation of Earth system models (ESMs).

Recent Findings The representation of marine biogeochemistry has progressed within the current generation of Earth system models. However, it remains difficult to identify which model updates are responsible for a given improvement. In addition, the full potential of marine biogeochemistry in terms of Earth system interactions and climate feedback remains poorly examined in the current generation of Earth system models.

This article is part of the Topical Collection on Carbon Cycle and Climate

Electronic supplementary material The online version of this article (https://doi.org/10.1007/s40641-020-00160-0) contains supplementary material, which is available to authorized users.

Roland Séférian

roland.seferian@meteo.fr

1 CNRM, Université de Toulouse, Météo-France, CNRS, Toulouse, France

2 National Oceanography Centre, European Way, Southampton SO14 3ZH, UK

3 LMD-IPSL, Ecole Normale Supérieure / Université PSL, CNRS, Ecole Polytechnique, Sorbonne Université, Paris, PSL University, Paris, France

4 School of Environmental Sciences, University of Liverpool, Liverpool, UK

5 LOCEAN Laboratory, Sorbonne Université-CNRS-IRD-MNHN, Paris, France

6 Canadian Centre for Climate Modelling and Analysis, Victoria, BC, Canada
7 NOAA/Geophysical Fluid Dynamics Laboratory, Princeton, NJ, USA

8 LSCE-IPSL, Université Paris Saclay, Gif-sur-Yvette, France

9 Max Planck Institute for Meteorology, Hamburg, Germany

10 National Center for Atmospheric Research, Boulder, CO, USA

11 JMA Meteorological Research Institute, Tsukuba, Japan

12 NASA Goddard Institute for Space Studies, New York, USA

13 NORCE Climate, Bjerknes Centre for Climate Research, Bergen, Norway

14 Present address: Los Alamos National Laboratory, Los Alamos, NM, USA

15 Research Center for Environmental Modeling and Application, Japan Agency for Marine-Earth Science and Technology (JAMSTEC), Yokohama, Japan

16 Beijing Climate Center, China Meteorological Administration, Beijing, China 
Summary Increasing availability of ocean biogeochemical data, as well as an improved understanding of the underlying processes, allows advances in the marine biogeochemical components of the current generation of ESMs. The present study scrutinizes the extent to which marine biogeochemistry components of ESMs have progressed between the 5th and the 6th phases of the Coupled Model Intercomparison Project (CMIP).

Keywords Marine Biogeochemistry $\cdot$ CMIP5 $\cdot$ CMIP6 $\cdot$ Biogeochemistry-Climate Feedbacks $\cdot$ Model Performance

\section{Introduction}

Marine biogeochemistry plays a key role in the Earth system. By regulating the exchange of $\mathrm{CO} 2$ and other climatically active gases with the atmosphere [1], it is involved in a large range of climate feedbacks [2]. As a result, changes in ocean biogeochemistry can have important consequences for climate [3-5]. Marine biogeochemistry is also deeply interwoven with the functioning of marine ecosystems and ultimately food webs [6-8]. Marine ecosystems are affected by anthropogenic environmental change [9-11], particularly through climateinduced changes in physical properties and $\mathrm{CO}_{2}$-induced ocean acidification [12-16]. Understanding and quantifying the response of ocean biogeochemistry to global changes, as well as its role in Earth system feedbacks [12, 17], are essential to improve our capacity to project ecosystem services and climate change in this century and beyond.

In this context, ocean biogeochemical models are acknowledged as powerful tools to study the ocean carbon cycle and its response to past and future climate and chemical changes [2]. Since the pioneering assessment of anthropogenic carbon uptake by the ocean by Maier-Reimer and Hasselmann [18] and Sarmiento et al. [19], and the Ocean Carbon Model Intercomparison Project (OCMIP) of Orr et al. [20], ocean biogeochemical models have been successfully integrated in many Earth system models (e.g. [21-31]).

Over the last few decades, the results from ocean biogeochemical models running within ESMs have increasingly been used to drive research on the carbon cycle. Their results have supported the assessment of carbon cycle feedbacks [32-35] and have improved the understanding of mechanisms behind the near-linear transient climate response to cumulative $\mathrm{CO}_{2}$ emissions [36]. Consequently, they have helped determine the change in carbon budgets that is compatible with a given level of warming since pre-industrial times. Ocean biogeochemical models have also been used to investigate potential geoengineering solutions to climate change such as solar radiation management [37-39], ocean fertilization [40-47], alkalinity addition [48-52] and reversibility experiments (e.g. [53, 54]).

Recent advances in marine ecosystem modelling have also led to diversification in the use of ocean biogeochemistry models within ESMs to study a wide range of potential impacts [55-58]. These research activities are now grouped under the umbrella of the Inter-Sectoral Impact Model Intercomparison Project (ISIMIP), with the FishMIP initiative being a specific example for fisheries impacts [59, 60].

Over recent years, models are increasingly being used in a semi-operational mode to aid with investigations of the predictability of key policy-relevant ocean biogeochemistry fields (e.g. net primary productivity, ocean acidity, ocean carbon uptake) [61-67]. Because of their close relationship with important living marine resources, skillful predictions of these properties have led to ocean biogeochemistry models being recognized as valuable tools when developing environmental policies (e.g. [68]) or designing fisheries management [64, 65, 69].

Because this large array of applications goes well beyond the conventional scientific investigation of the ocean carbon cycle, marine biogeochemical models have been developed in a number of directions over recent years. These developments are generally supported by progress in process understanding, which in turn is driven by an increasing number of observational databases [70-72]. However, from one generation to another, the development of marine biogeochemical models is driven not only by common scientific considerations but also by the internal priorities of individual modelling groups. As a consequence, it is difficult to anticipate how far the representation of marine biogeochemistry within the current generation of Earth system models differs from-and has improved upon - the previous one.

The present study maps the changes or updates in ocean biogeochemistry components that have arisen between CMIP5 and CMIP6 and assesses how far these have led to actual improvements in model skill against present-day observations. Overall, our assessment demonstrates that the simulated mean state of ocean biogeochemistry models in CMIP6 is more realistic than that produced by their CMIP5 analogues in many aspects, but that it remains difficult to clearly identify which changes in a given ocean biogeochemistry model are responsible for these improvements.

\section{Mapping Changes or Updates in Ocean Biogeochemistry}

In this section, we review the changes or updates implemented by participating modelling groups. The following method was 
employed to collect relevant model details as shown in Table 1. First, all of the modelling groups contributing both to CMIP5 and CMIP6 were approached. Next, a questionnaire in the form of a spreadsheet was proposed and developed. This sought details around (1) model resolution, (2) complexity in marine biology, (3) the representation of bacteria, (4) internal physiology, (5) organic matter cycling, (6) sediments, (7) nutrients and elemental cycling, (8) the level of interactions with the other components of the Earth system and (9) modelling approaches including spin-up protocols and tuning/calibration. The latter includes external inputs/ outputs and biophysical interactions. The resulting master table of model properties is provided in Supplementary materials (Table S1).

Tables 1, 2 and 3 map the key updates made between CMIP5 and CMIP6 (full details are available in Table S1). Table 1 suggests that most of the changes have tried to address at least one missing process of major importance for marine biogeochemistry, as highlighted in IPCC AR5 ([2], page 499), that is, representation of the lower trophic level including bacteria, organic matter cycling including sinking particles or variation in stoichiometric ratios.

Table 1 includes a brief overview of the key updates in ocean physics between CMIP5 and CMIP6 because marine biogeochemistry is prominently driven by ocean circulation (large-scale circulation and mesoscale eddies) and vertical mixing.

Table 1 tracks not only updates in the horizontal and vertical resolution of physical ocean models but also changes in related ocean physical parameterization. As suggested by Griffies et al. [103], an increase in horizontal or vertical resolution enables the representation of finer-scale ocean physical processes (e.g. mesoscale eddies) in relation with the activation of more realistic ocean physical parameterizations (such as vertical mixing, diurnal cycle or coupling with the atmosphere).

The first common difference between CMIP5 and CMIP6 ESMs comes from the ocean-sea ice components. Indeed, it is interesting to note that $8 \mathrm{ESM}$ groups out of 12 use an upgraded version of the ocean models or employ a new ocean model (Table 1). These changes imply substantial updates or revisions in ocean physical parameterizations that may have an impact on large-scale circulation and vertical mixing.

In addition, another common difference between ocean models used in CMIP5 and CMIP6 is the grid resolution. It is interesting to note that all of the ocean models, with the exception of MPI-ESM1-2-LR, now resolve ocean dynamics at a minimum horizontal nominal resolution of $100 \mathrm{~km}$. The highest horizontal nominal resolution in the available multimodel ensemble is $50 \mathrm{~km}$ (GFDL-ESM4). Despite this general increase in horizontal resolution, only GFDL-CM4 uses an eddy-permitting ocean model $(\sim 25 \mathrm{~km})$. In addition, the current generation of ocean models also better represent vertical physical processes with a typically finer vertical resolution.

Another common difference between the two generations of models is the complexity of the marine ecosystem description and related parameterizations. Here, the complexity encompasses the diversity of model trophic web (i.e. the number of specific model phytoplankton and zooplankton types), the representation of bacteria, ecosystem functioning including macro- and micro-nutrient limitation (e.g. iron), and the variation in modelled stoichiometric ratios of carbon, nitrogen and other elements (e.g. photosynthetic pigment). Greater complexity does not necessarily imply a better representation of cycles and processes associated with each biogeochemical species, as it may introduce new degrees of freedom and/or non-linear (or at least not well controlled) interactions between parameterizations.

Table 1 shows that ocean biogeochemistry models span a wide range of complexity levels. The simplest models use ocean carbon cycle models based on the OCMIP protocol [20] that do not include marine biota or nutrients. Meanwhile, the most complex models include a broad trophic structure that groups marine organisms into plankton functional types based on their biogeochemical role, with mechanistic representations of nutrient limitation and variable stoichiometric ratios.

Table 1 also highlights noticeable changes in biogeochemical parameterizations between CMIP5 and CMIP6. They concern 10 biogeochemical models out of 12 reviewed in this study. These changes may be related to the change in model complexity or to a revised set of parameterizations (e.g. nitrogen fixation, remineralization, grazing, flux feeding; see Table S1).

We map updates and changes in ocean biogeochemical models along three major axes; axis 1 . The trophic food web, the plankton internal physiology (e.g. variable stoichiometry, chlorophyll pigment) and nutrients cycling (iron cycle, nutrients cycles). This axis aims to track updates in biogeochemical dynamics and ecosystem functioning; axis 2 . The external sources of nutrients; axis 3. The interactions of marine biogeochemistry with climate or ocean physics. The latter two axes track the level of integration of the marine biogeochemical model in the modelled Earth system.

It is important to stress that an increase or a decrease along one of those three axes does not necessarily imply an improvement in model performance or skill. In most cases, it reflects progress in process understanding (physical, biogeochemical or both), the inclusion of new Earth system interactions or the representation of climate feedbacks is required to investigate future scenarios.

Table 1 shows that the current generation of CMIP6 displays a greater diversity of marine biogeochemical models than CMIP5. 


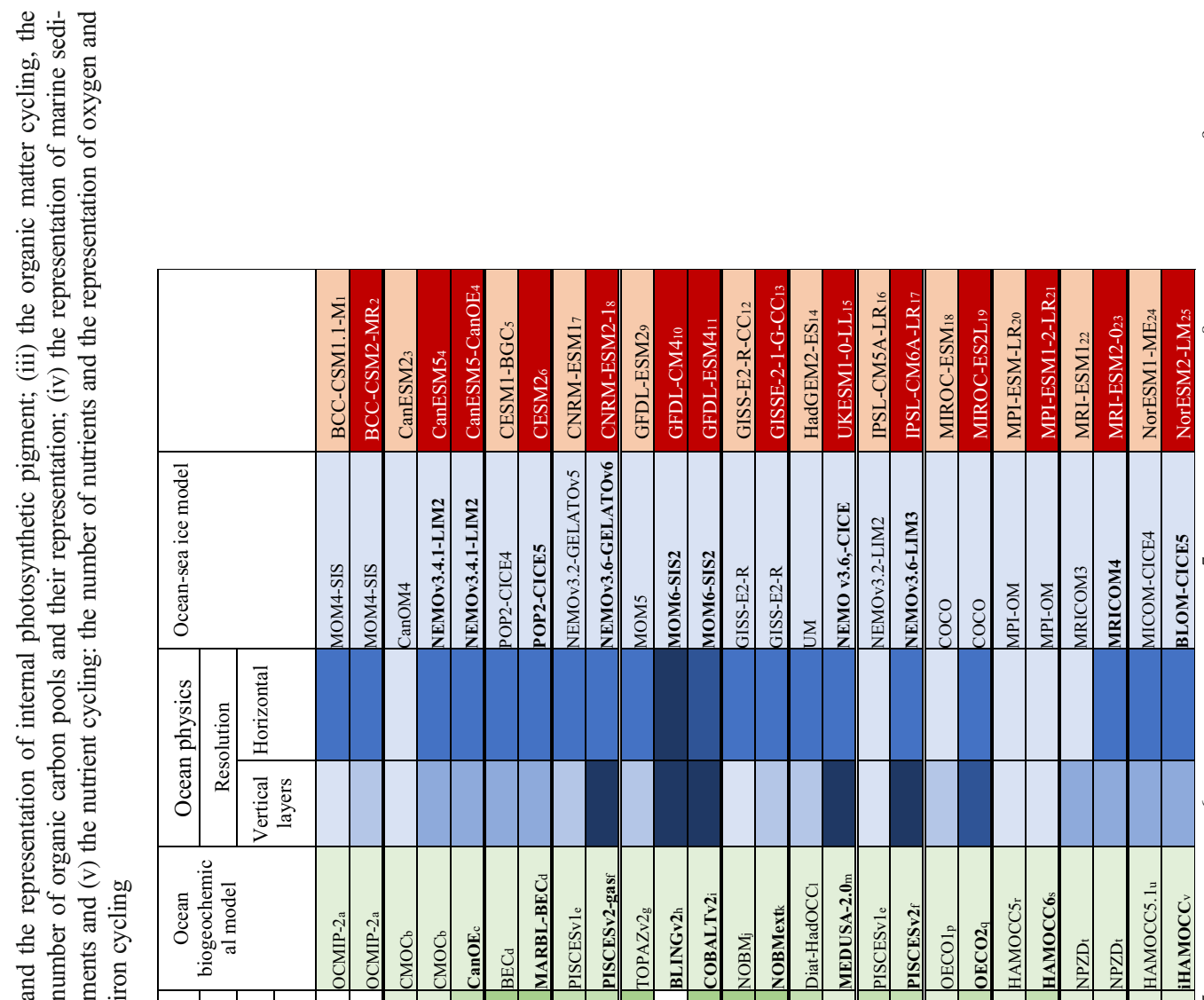

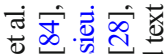

元䊉

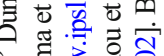

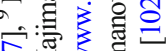
을

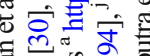

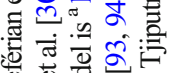
क ठ

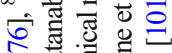
iे है $-\infty$ एक. 元 窝 n त्ञ

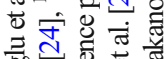
品

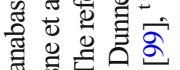

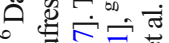
$\dot{0} \bar{\infty} \overline{0}$ 느 तं त्ष

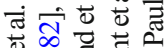
宛专完

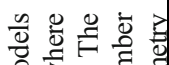
学富 过 感普 की

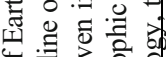

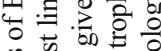

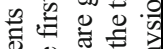

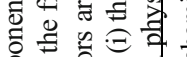

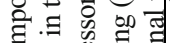
है

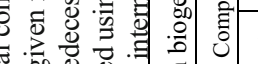

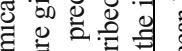

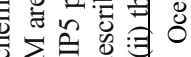

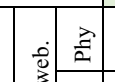
ป

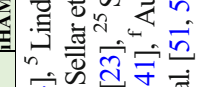

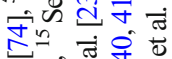
宁安

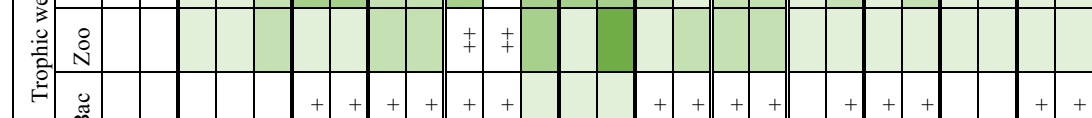

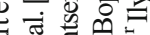

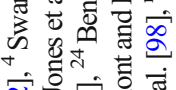

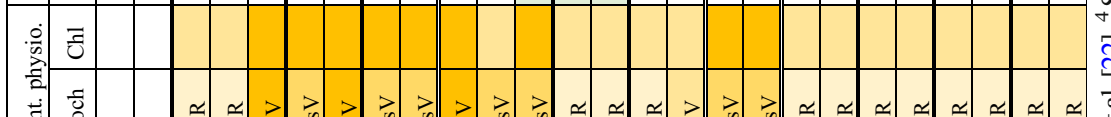

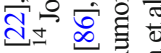
तं के बं

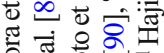

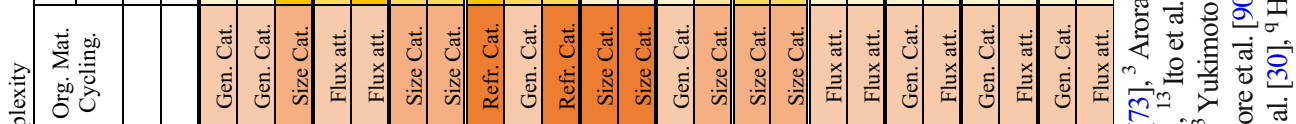
造记 $\sum_{0.0}$

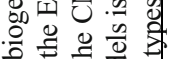
幽

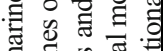

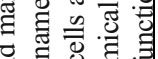
政 部导 造. 年 5

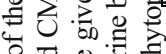
号

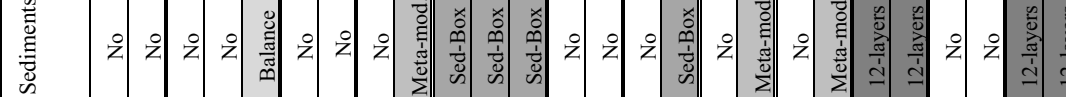
元

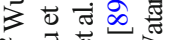
글

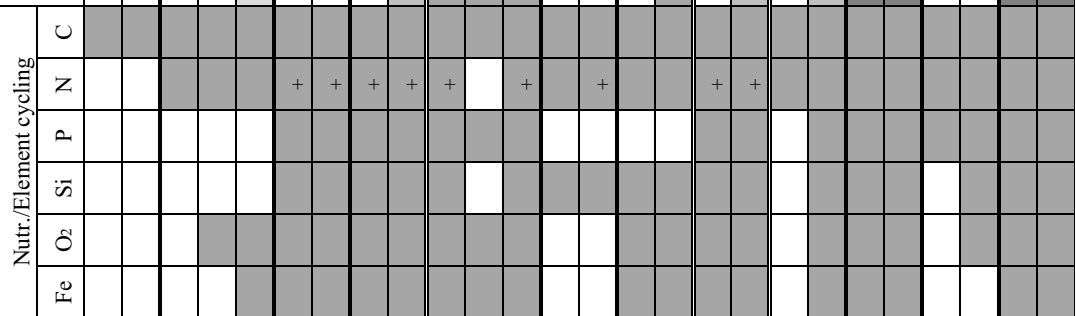

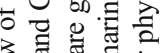
on

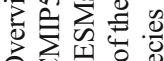
0 ठद 1000

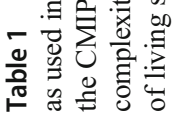

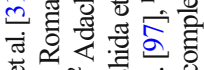
एत्र त्र ज्ञ

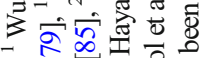

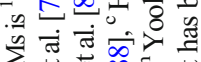

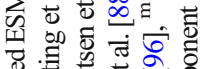

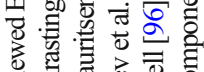

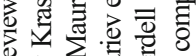

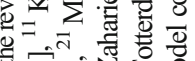

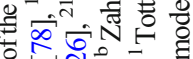

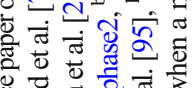

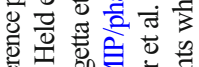

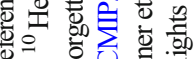

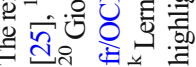


COBALTV2 (in GFDL-ESM 4), for instance, displays the highest trophic complexity level with 3 explicit phytoplankton classes, 1 implicit phytoplankton class, 3 explicit zooplankton classes and 1 explicit heterotrophic bacteria class; however, this model still employs a relatively simple parameterization of iron cycling. In comparison, PISCESv2-gas (in CNRMESM2-1) or PISCESv2 (in IPSL-CM6A-LR) includes 4 explicit plankton types (2 phytoplankton and 2 zooplankton), but two iron ligands and 5 iron forms [104]. MARBL-BEC (in CESM2) also includes an iron ligand and has opted for increasing ecosystem complexity by introducing variable $\mathrm{C}: \mathrm{P}$ stoichiometry, based on $\mathrm{PO}_{4}$ concentrations [105], while maintaining 4 plankton types. It is interesting to note that, while limiting the number of nutrients, CanESM5-CanOE have evolved toward a more comprehensive treatment of marine biogeochemistry with 4 explicit plankton types and using variable stoichiometry [89]. In contrast with a general increase in complexity, NOAA-GFDL has started to use a reduced complexity marine biogeochemical model embedded in the high-resolution ocean model of GFDL-CM4. This approach implies a trade-off between computational costs and essential biogeochemical processes to represent the ocean carbon cycle as explained in Galbraith et al. [105]. Such diversity tends to mirror progress in the understanding of the impact of variable stoichiometric ratios on ecosystem dynamics and carbon assimilation by phytoplankton cells [106-110].

Table 1 shows that all CMIP6 models except GFDL-CM4 have evolved toward a more comprehensive treatment of elemental cycling including nitrogen, oxygen and iron cycling. This moderate increase in model complexity is supported by recent observations in phytoplankton functioning, nutrient limitation or plankton physiology [111-116] and the availability of a larger array of observational data (bio-ARGO and GEOTRACES) supporting the model evaluation and development (e.g. Tagliabue et al. [117]). On the other hand, this increase in complexity is also encouraged by the growing range of applications to which ESMs are being dedicated (e.g. marine resource applications as investigated in Lotze et al. [59] or Park et al. [64]).

Finally, Table 1 shows that all CMIP6 models have progressed toward a better representation of marine organic carbon cycling, sinking particles and marine sediments. In most cases, this component of marine biogeochemistry is parameterized using either a sediment box module or a metamodel based on downward fluxes of organic matter. Indeed, for several CMIP6 marine biogeochemical models, a more complex representation of sinking particles and organic matter pools (refractory classes or flux attenuation parameterization) replaces the generalized pools of organic matter used in the CMIP5 predecessors.

Table 1 also sheds light on noticeable changes in the representation of sediment interactions. Most of the reviewed CMIP6 ESMs now simulate this compartment with biogeochemical parameterization (e.g. balance, meta-model, sediment box) or with a comprehensive sediment module (12-layer sediments module).

Table 2 also shows that the representation of the external sources of nutrients (i.e. the third axis of our model complexity breakdown) has grown in complexity between CMIP5 and CMIP6. It mirrors a more comprehensive treatment of boundary conditions between ESM components (atmosphere, rivers, glaciers, etc.). Most of the current generation of ocean biogeochemical models now consider inputs of biogeochemical elements via atmospheric deposition or from rivers. The iron delivery from sediment mobilization, hydrothermal sources or ice melting is additionally considered by a small set of models. This reflects recent advances in understanding the global iron cycle [111-116]. In contrast, despite a better understanding of the role of submarine water discharge in ocean nutrient supply [118-121], this particular boundary condition is not considered in the current generation of ocean biogeochemical models.

Besides, it is interesting to note that a couple of CMIP6 ESMs now includes a more comprehensive treatment of interactions between the marine biogeochemistry and the other Earth system components. For instance, GFDL-ESM 4 simulates interactively most of the primary source of iron for marine biogeochemistry (atmospheric dust deposition, iceberg melting and river supply), enabling the representation of biogeochemical couplings observed in the real world (e.g. [122]).

Table 2 highlights that the current generation of ESMs displays a wider range of Earth system feedbacks or interactions. In our review, we have decomposed Earth system interactions involving marine biogeochemistry along two axes: (1) the air-sea exchange of greenhouse gases or reactive chemical compounds interacting with Earth's radiative budget (and hence climate); (2) the represented Earth system interactions involving marine biogeochemistry (including the air-sea exchange of greenhouse gases or reactive chemical compounds and biophysical interactions); that is, what is really contributing to the Earth system model climate. This latter has been mapped into 4 feedbacks: climate-carbon cycle feedbacks (F1), biogenic aerosol-cloud feedbacks (F2), non- $\mathrm{CO}_{2}$ biogeochemical cycle feedbacks (F3) and phytoplankton-light feedbacks (F4).

The influence of ocean dimethylsulfide (DMS) emissions on cloud albedo is an example of the biogenic aerosol-cloud feedback (F2). DMS is a breakdown product of dimethylsulfoniopropionate (DMSP), a metabolite in many phytoplankton with a role as a cellular osmolyte/antioxidant $[123,124]$. It is exchanged with the atmosphere and is involved in the formation of sulfur aerosols once it is oxidized there. As the other sulfate aerosols, DMS may be involved in the formation of cloud condensation nuclei $(\mathrm{CCN})$. The potential importance of ocean DMS emissions for the climate 
चี

过谣

응

ज记

능 है

毛焉

㣢些焉

흥 券

$\exists . \underbrace{}_{0}$

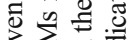

कo

要这

动表家

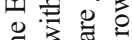

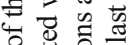

论 卷

娄

은 능

을 要

$\sum \delta$

के है

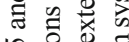

期总歪

ठ एँ

$\exists$

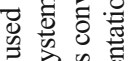

के

穿边

웜

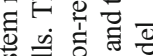

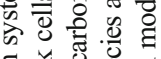

青总额

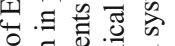

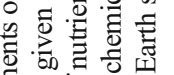

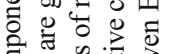

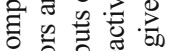

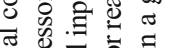

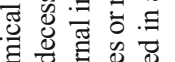

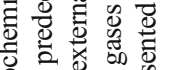

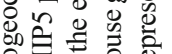

융 它远

范要

물 형

需

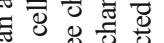

8 可

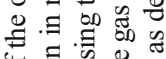

\begin{tabular}{|c|c|c|c|c|c|c|c|c|c|c|c|c|c|c|c|c|c|c|c|c|c|c|c|}
\hline & & & 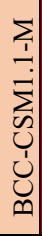 & 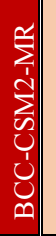 & 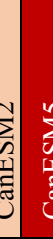 & 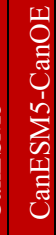 & 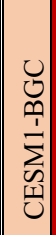 & 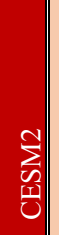 & 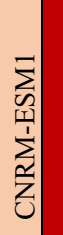 & 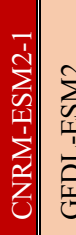 & 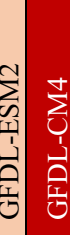 & 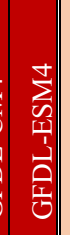 & 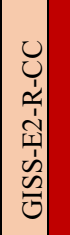 & 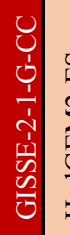 & 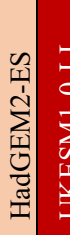 & 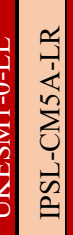 & 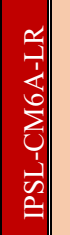 & 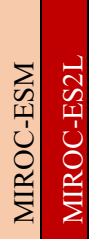 & 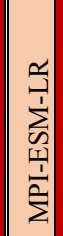 & 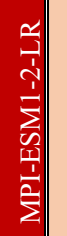 & $\begin{array}{l}\sum_{\infty} \\
\overline{1} \\
\frac{1}{2} \\
\Sigma\end{array}$ & 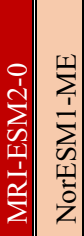 & 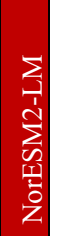 \\
\hline & & 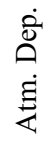 & & & & ષ & $z$ & $\begin{array}{l}\sim \\
\sim \\
\bar{w} \\
\alpha \\
z \\
z\end{array}$ & $\begin{array}{l}\stackrel{0}{\sqcup} \\
z\end{array}$ & \begin{tabular}{l||l}
$\stackrel{0}{L}$ & $\dot{0}$ \\
$z$ & $u$ \\
$z$
\end{tabular} & $\begin{array}{lll}\nu & \nu \\
\nu \\
z \\
z\end{array}$ & $\begin{array}{l}= \\
= \\
= \\
= \\
2 \\
z\end{array}$ & $\stackrel{\nu}{\sqcup}$ & $\stackrel{\mathcal{\nu}}{\llcorner}$ & $\stackrel{\Xi}{\longleftarrow}$ & $\begin{array}{l}\stackrel{0}{山} \\
z^{-}\end{array}$ & \begin{tabular}{l|} 
\\
\\
$z$ \\
$z$
\end{tabular} & $\begin{array}{l}\stackrel{\nu}{\omega} \\
z\end{array}$ & $\stackrel{4}{\sqcup}$ & \begin{tabular}{l|l}
$\stackrel{\nu}{\perp}$ & \\
$z$ &
\end{tabular} & & ๖ & $\begin{array}{l}\Psi \\
\sim \\
z\end{array}$ \\
\hline & 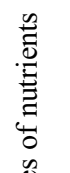 & $\begin{array}{l}\dot{\Xi} \\
\dot{\Xi} \\
\dot{\vec{n}}\end{array}$ & & & & & & \begin{tabular}{l||}
4 \\
$\bar{n}$ \\
0 \\
$z$ \\
$z$ \\
$u$
\end{tabular} & $\begin{array}{l}0 \\
u \\
0 \\
z \\
ن \\
ن\end{array}$ & 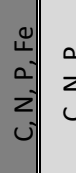 & 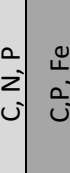 & $=$ & & $\begin{array}{l}\stackrel{\nu}{u} \\
\bar{n} \\
z \\
v \\
v\end{array}$ & & $\begin{array}{l}0 \\
4 \\
0 \\
z \\
z \\
u\end{array}$ & $\left|\begin{array}{l|}0 \\
u \\
0 \\
z \\
u \\
u\end{array}\right|$ & $\begin{array}{l}0 \\
z\end{array}$ & & & & & $\begin{array}{l}\tilde{u} \\
\bar{n} \\
z^{2} \\
v\end{array}$ \\
\hline & 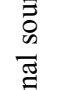 & $\begin{array}{l}\ddot{d} \\
\mathscr{n}\end{array}$ & & & & एँ & $\stackrel{\varpi}{\sqcup}$ & $\stackrel{\sim}{\llcorner}$ & $\stackrel{4}{\llcorner}$ & 岀 & $\stackrel{\varpi}{\sqcup}$ & $\stackrel{\sim}{\sim}$ & & & $\stackrel{\square}{4}$ & $\stackrel{\mathscr{\nu}}{\sqcup}$ & $\stackrel{\nu}{\llcorner}$ & Ф) & & & & & \\
\hline 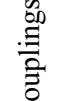 & $\begin{array}{l}\text { 离 } \\
\text { 离 }\end{array}$ & $\begin{array}{l}\dot{\overrightarrow{0}} \\
\text { ¿ँ }\end{array}$ & & & & & & Чั & & & & Чँ & & & & & & Чั & & & & & \\
\hline 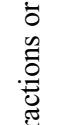 & & 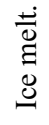 & & & & & & & & & & षు & & & & & & & & & & & \\
\hline 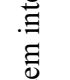 & & రీ & & & & & & & & & & & & & & & & & & & & & \\
\hline $\begin{array}{l}\vec{E} \\
\vec{E}\end{array}$ & $\stackrel{\infty}{=}$ & ชี & & & & & & & & & & & & & & & & & & & & & \\
\hline 凹్ & $\begin{array}{l}\text { 氙 } \\
\text { 离 }\end{array}$ & $\sum_{0}^{n}$ & & & & & & & & & & & & & & & & & & & & & \\
\hline & $\tilde{O}$ & $\begin{array}{l}\text { O } \\
\text { Ż }\end{array}$ & & & & & & & & & & & & & & & & & & & & & \\
\hline & & 齐 & & & & & & & & & & & & & & & & & & & & & \\
\hline & & $\vec{I}$ & & & & & & & & & & & & & & & & & & & & & \\
\hline & 总 & I & & & & & & & & & & & & & & & & & & & & & \\
\hline & 苛 & $\underline{I}$ & & & & & & & & & & & & & & & & & & & & & \\
\hline & & 喆 & & & & & & & & & & & & & & & & & & & & & \\
\hline
\end{tabular}

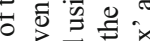

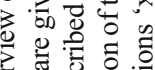

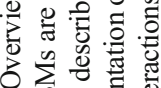

部苛焉

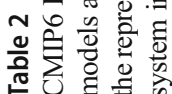

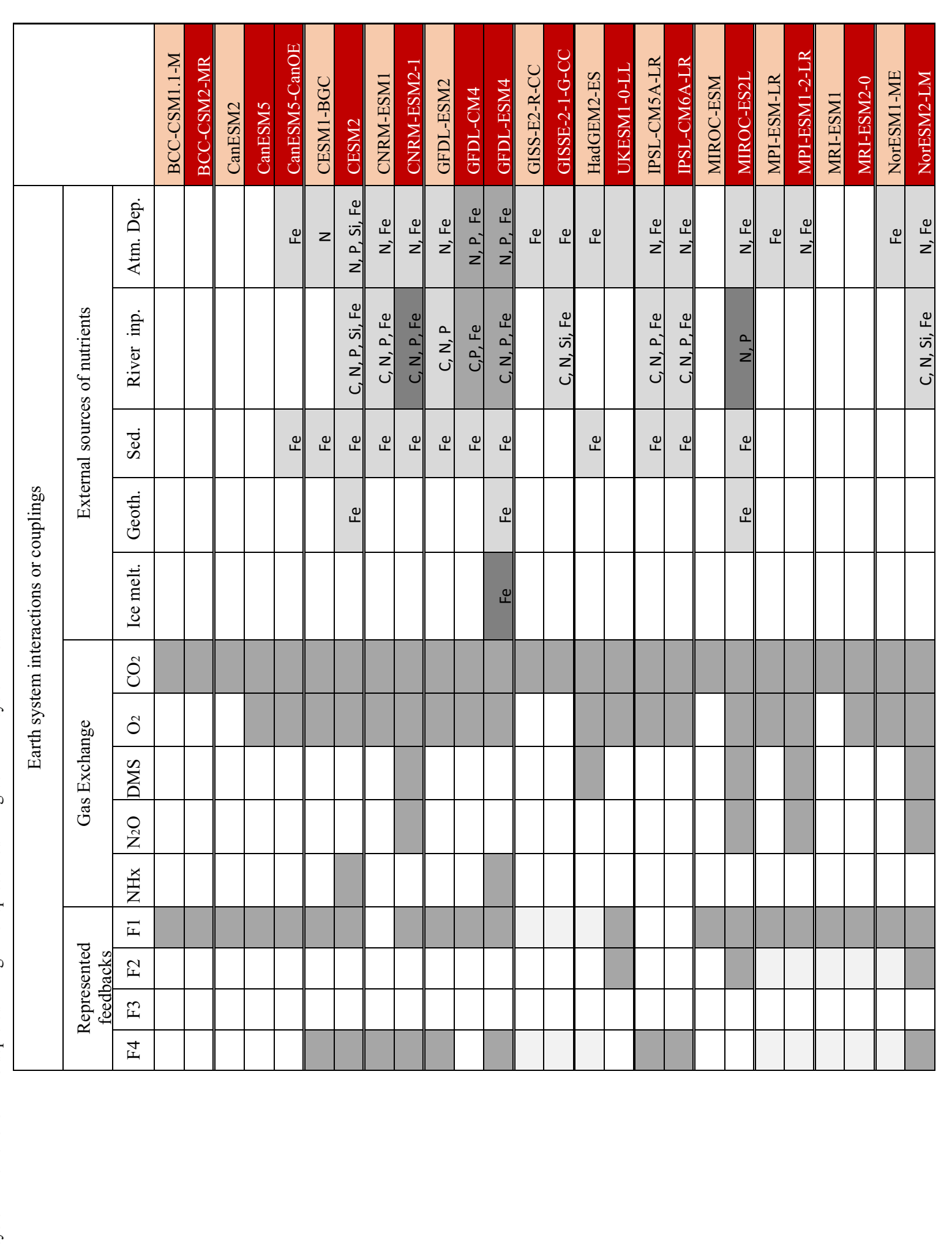




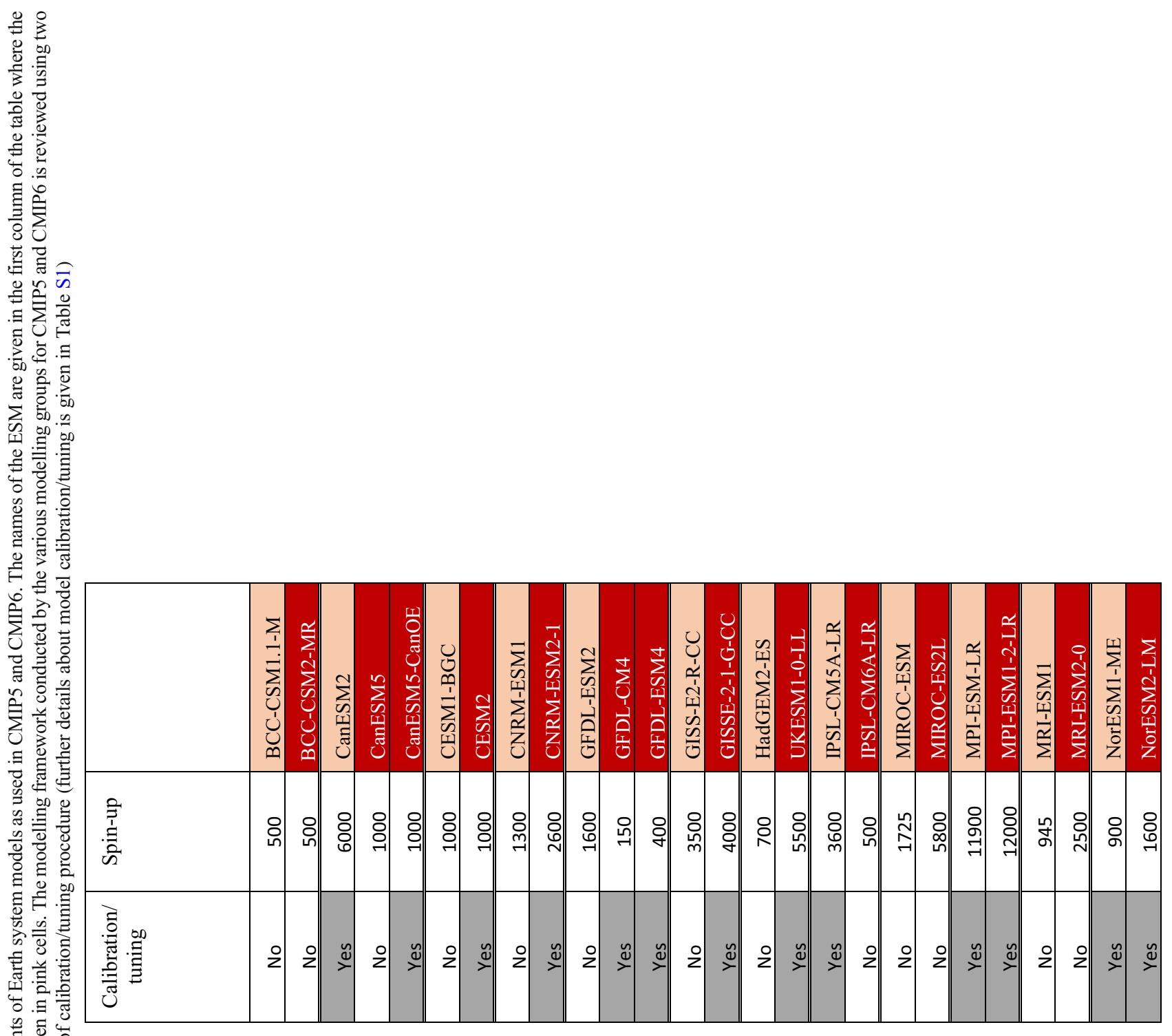

है

on

言 苞

त्र

远递

品

光

魚辤

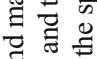

空

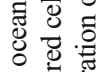

$\stackrel{\Xi}{\Xi}$

4 है

30

变

0 虫

m 
system is still largely debated [125] because modern observations do not support its prominent role in the formation of CCN [126-128]. However, long-term measurement [129] and mesocosm experiments (e.g. [17]) suggest that global changes may impact the rate of ocean DMS emissions. Recent modelling studies argue for a potential role of ocean DMS in future climate change (e.g. $[130,131])$. Ocean $\mathrm{NH}_{\mathrm{x}}$ emissions are also involved in biogenic aerosol-cloud feedbacks (F2). Kirkby et al. [132] suggest that $\mathrm{NH}_{\mathrm{x}}$ can also play an important role in the formation of secondary nitrate aerosols in the atmosphere. Similarly to DMS, these aerosols can serve as $\mathrm{CCN}$ and contribute to changes in cloud albedo. Non$\mathrm{CO}_{2}$ biogeochemical cycle feedbacks (F3) involve ocean emissions of non- $\mathrm{CO}_{2}$ greenhouse gases (e.g. $\mathrm{N}_{2} \mathrm{O}$ or methane) or any chemical compounds contributing to the generation of greenhouses gases (e.g. methane, carbon monoxide). The phytoplankton-light feedbacks (F4) represent the suite of biophysical mechanisms that involve the influence of the marine biota on the upper ocean physics through the vertical redistribution of heat.

Table 2 confirms that all ocean biogeochemical models account for the climate-carbon cycle feedback since CMIP5 (Earth system feedback F1 in Fig. 1). In addition, Table 1 shows that the current generation of ocean biogeochemical models includes an air-sea gas exchange for a larger number of radiatively active biogeochemical compounds such as DMS, nitrous oxide $\left(\mathrm{N}_{2} \mathrm{O}\right)$ and ammonia $\left(\mathrm{NH}_{\mathrm{x}}\right)$. The inclusion of climate active gases or greenhouse gases other than $\mathrm{CO}_{2}$ in the current generation of ocean biogeochemical models is a result of the increased recognition of the importance of these compounds in Earth system interactions with aerosols, atmospheric chemistry and, potentially, with clouds.

In particular, the inclusion of ocean $\mathrm{NH}_{\mathrm{x}}$ or $\mathrm{N}_{2} \mathrm{O}$ emissions in ocean biogeochemical models has been driven by a better understanding of the global nitrogen cycle and its role in climate change. In particular, the development of databases such as MEMENTO (https://memento.geomar.de/) has enabled better validation and calibration of $\mathrm{N}_{2} \mathrm{O}$ modules in global ocean biogeochemical models [133-138].

However, the inclusion of Earth system feedbacks as illustrated in Fig. 1 has not in all cases progressed between CMIP5 and CMIP6. For example, biophysical interactions with the ocean radiative transfer (F4 in Fig. 1) are overlooked by more than half of the marine biogeochemical models examined, although this feedback is well documented and relatively well understood $[139,140]$.

Our review of available ESMs suggests that the current generation of marine biogeochemical models has not much evolved toward comprehensive couplings between Earth system components and ocean biogeochemistry or toward improved treatment of biophysical and biogeochemical feedback with respect to their predecessors (F1 and F4 in Fig. 1). The full impact of ocean biogeochemistry on climate and its role in
Earth system feedback remains far from being entirely represented in the current generation of Earth system models, as it involves different spatial and temporal scales that models are not currently able to reach and also processes still poorly understood.

Finally, our review suggests that the modelling approaches have evolved between CMIP5 and CMIP6. These latter have been monitored with two key indicators: (1) the length of the spin-up simulation and (2) the use of calibration/tuning for marine biogeochemical parameters. These two key indicators were discussed in published literature (e.g. Séférian et al. [76] or Hourdin et al. [141]), reflecting, in general, an improved knowledge in model characteristics (strength and deficiency).

Table 3 and Table S1 highlight that most of the modelling groups have expanded the duration of the spin-up for CMIP6. This represents an important effort of the scientific community to converge toward recommended standards (e.g. [142]). Only GFDL and IPSL have reduced the duration of their spin-up protocol for computing reasons: they manage to fulfil CMIP6 standard in a few hundreds of years. On the other hand, it is noticeable that several modelling groups have included a step of model calibration or tuning in CMIP6. Our review suggests that this step has been motivated by various reasons: bias reduction for key biogeochemical fields in CNRM, GFDL or NorESM or bias compensation to reduce the impact of known biases in simulated surface chlorophyll for ocean DMS and organic aerosols emissions in UKESM. There is no consensus between modelling groups on how model calibration or tuning takes place in the model preparation. Depending on modelling group, the calibration or tuning is either included in the model development or during the spin-up procedure (Table S1).

\section{Tracking Model Performance Across Two Generations of Models}

Figures 2, 3, 4 and 5 illustrate the performance of the current generation of ESMs taking part in CMIP6, together with their predecessor CMIP5 models, for a range of climatological biogeochemical properties that are central to the carbon cycle and ecosystem applications: the sea-to-air flux of $\mathrm{CO}_{2}$, ocean chlorophyll, nitrate, silicate, oxygen and iron (see Methods in Supplementary materials). For Figs. 2, 3 and 4, observationbased estimates of each property are shown at the top of the figure, followed by the biases found across the current and last generation models. We note that, in several cases, observation-based estimates are derived from significant processing of sparse observations or from algorithms relating the quantity of interest to directly observed quantities (e.g. sea-toair $\mathrm{CO}_{2}$ flux, satellite chlorophyll). As such, the observations themselves are also subject to uncertainty which will be discussed in the context of each comparison. 


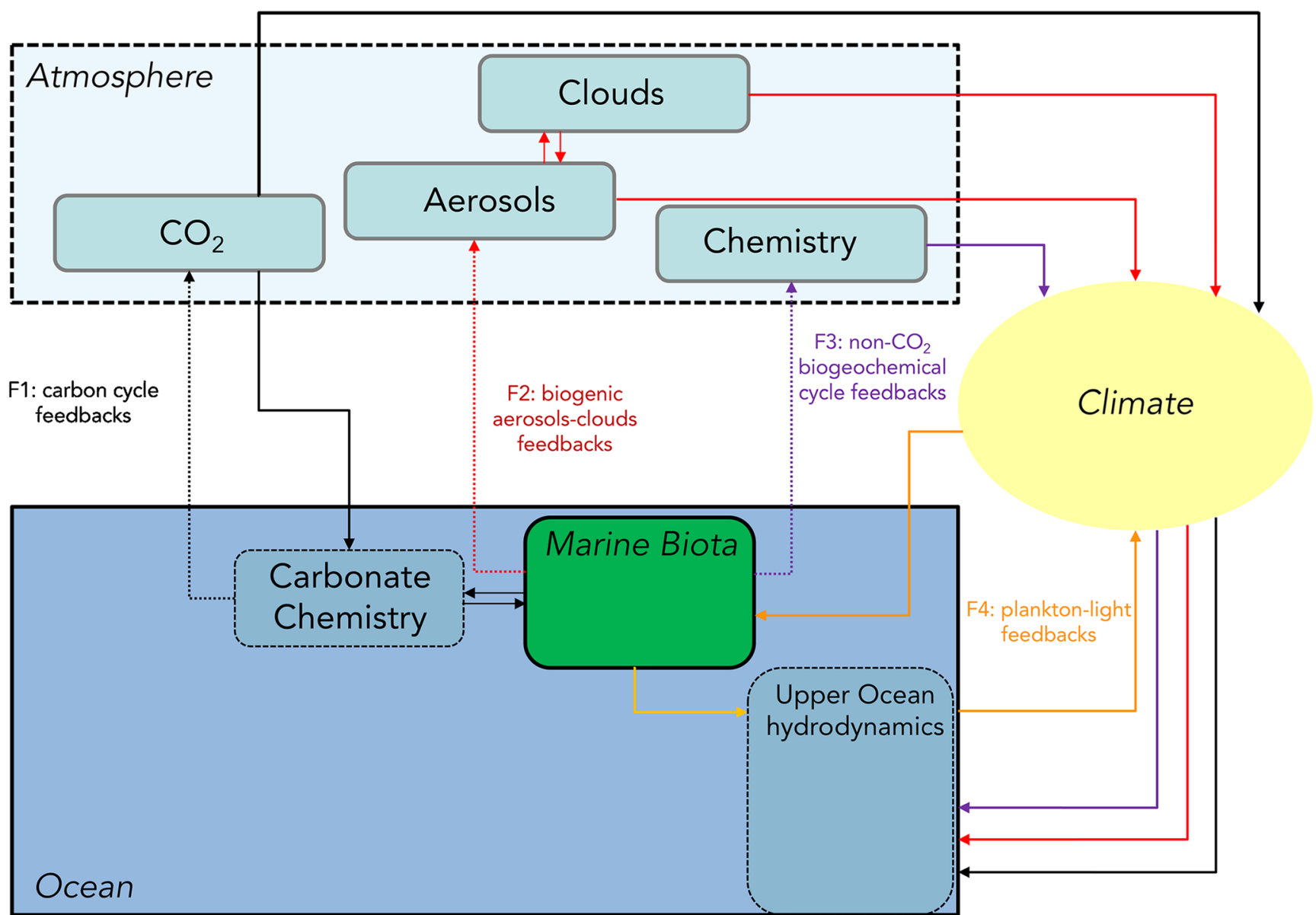

Fig. 1 Schematic representation of Earth system interactions and feedbacks between the ocean biogeochemistry and climate. F1 represents the well-established climate-carbon cycle feedbacks; F2 and
F3 sketch the dominant pathways for the biogenic aerosol-cloud feedbacks and the non- $\mathrm{CO}_{2}$ biogeochemical cycle feedbacks; F4 depicts the phytoplankton-light feedbacks (that is a biophysical interactions)
In Fig. 2a, the sea-to-air flux of the critical greenhouse gas, $\mathrm{CO}_{2}$, is shown, with a data product based on the mapping of observational $\mathrm{pCO}_{2}$ data drawn from the Landschützer et al. [143] product (1995-2014). The key geographical features of this are strong outgassing (i.e. a net sea-to-air flux) in upwelling regions, most clearly in the tropics and along the equatorial region of the Pacific Ocean, and ingassing (i.e. a net air-tosea flux) at temperate and subpolar latitudes. These features reflect processes that are governed by temperature, patterns of deep water formation, surface biological production and the thermohaline circulation.

In general, both CMIP5 and CMIP6 generations of models show a mixture of positive and negative biases across the globe with disagreement in the sign of the carbon fluxes over some regions. Common patterns are slightly negative biases both in the equatorial Pacific (i.e. weak outgassing) and in the North Atlantic (i.e. excessive ingassing). Both generations of models show a mix of relatively small positive and negative biases, except for the CMIP5 CanESM2 which shows the largest model-data error across the model ensemble. However, the comparison with observations has been substantially improved in CanESM5. More generally, Fig. 2a highlights that the improvement in simulated sea-toair carbon flux is clearer when looking at the direction of the carbon flux. This improvement seems to be linked to an improved representation of ocean vertical mixing (see skill scores of the ocean mixed-layer depth below). Indeed, all CMIP6 models exhibit smaller domains where the direction of the sea-to-air carbon flux disagrees with observations, except for MPI-ESM1-2-LR, which used the same ocean model and displays the same pattern of model-data disagreement for CMIP5 and CMIP6.

Figure $2 \mathrm{~b}$ shows surface chlorophyll, compared with satellite-based estimates derived from ESA-CCI-OC ocean colour data [144]. The key geographical features are relatively high concentrations in productive temperate, subpolar and upwelling regions, and extremely low concentrations in the unproductive subtropical gyres. The latter are dominated by perennially low-nutrient conditions, while the former experience frequent, or seasonal, introduction of nutrients by upwelling or deep mixing. While these general biome scale patterns are robust across satellite algorithms, we note that estimates 
Fig. 2 Model-data

intercomparison of a open oceansea-air carbon fluxes (fgco2, $\mathrm{g} \mathrm{C} \mathrm{m}^{-2}$ year $^{-1}$ ) and $\mathbf{b}$ open ocean surface chlorophyll (chl,

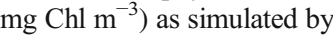
ocean biogeochemical models embedded within CMIP6 Earth system models (the right column) and their former version as used for CMIP5 (the left column). a The first top panel shows observation-based estimates from Landschützer et al. [143] averaged for the period 1995-2014 (see Methods in Supplementary materials). The other panels show model-data biases averaged for the same period. Coloured areas are indicative of the model-data absolute difference in magnitude of sea-air fluxes. Red regions indicate areas in models where the magnitude of the sea-air flux is greater than that observed, whereas blue regions indicate the reverse. $\mathbf{b}$ The first top panel shows satellite-based ocean chlorophyll estimates from ESA-CCIOC [144] averaged over 19982014. The other panels show model-data departure averaged over the period 1998-2014
Observations (Open Ocean fgco2)
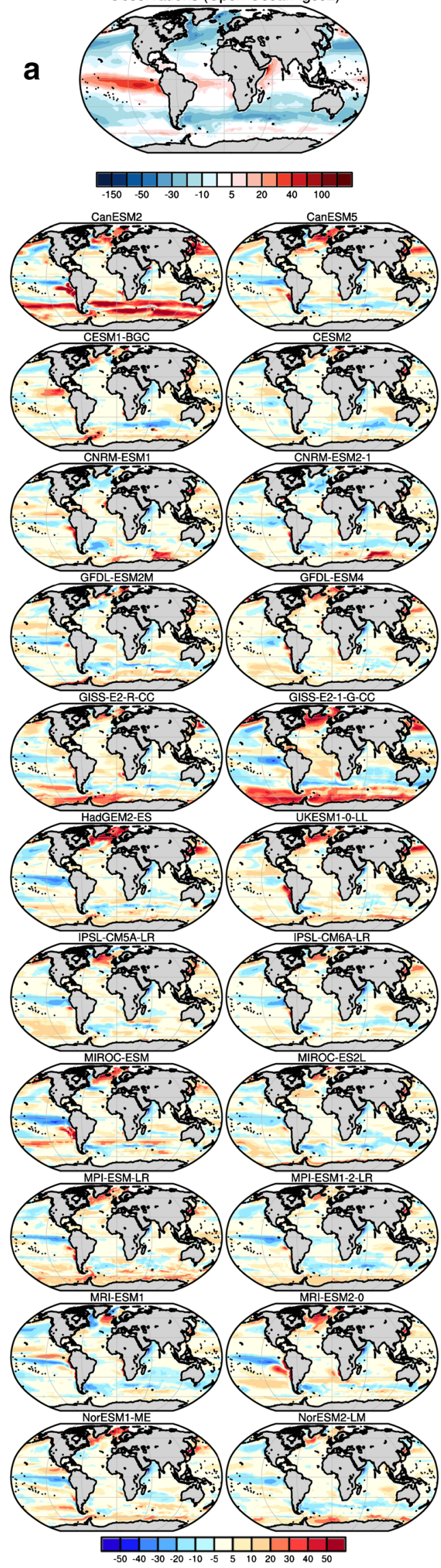

Observations (Open Ocean Surface Chlorophyll)

b
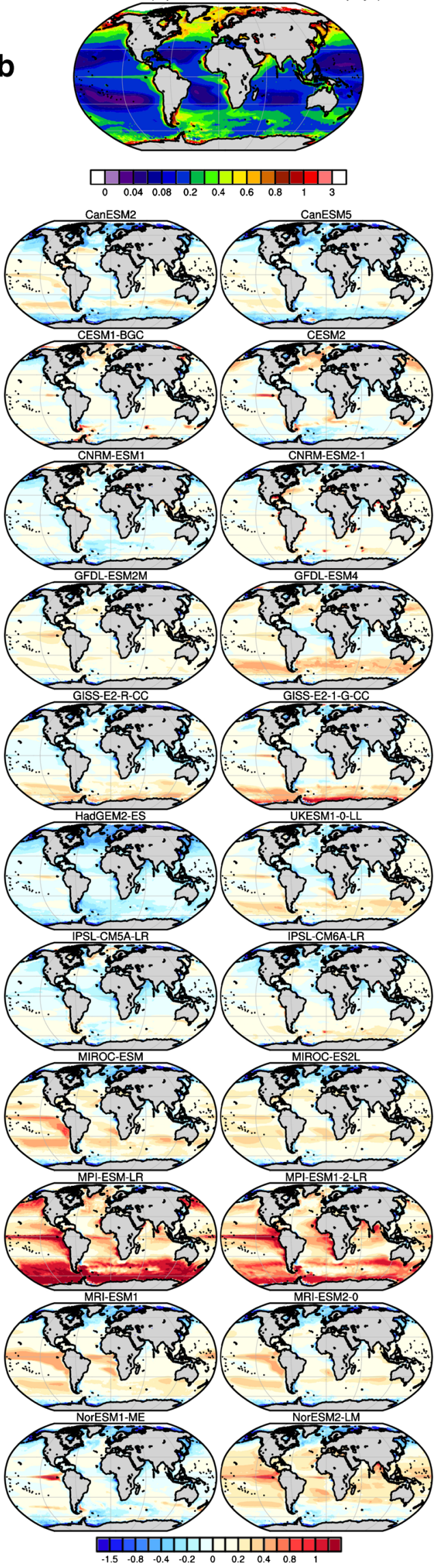
Fig. 3 Model-data

intercomparison of a surface nitrate concentrations (no3, $\mu \mathrm{mol} \mathrm{L}{ }^{-1}$ ) and $\mathbf{b}$ surface silicic acid concentrations (si, $\mu \mathrm{mol} \mathrm{L}^{-1}$ ) as simulated by ocean biogeochemical models embedded within CMIP6 Earth system models (right columns) and their former version as used for CMIP5 (left columns). $\mathbf{a}$ and $\mathbf{b}$ The first top panel shows the optimal interpolation of nitrate (no3) and silicate (si) measurements as provided in the World Ocean Atlas Database 2013 (Garcia et al. [145]). The other panels show model-data departure averaged over the period 1995-2014 (see Methods in Supplementary materials)
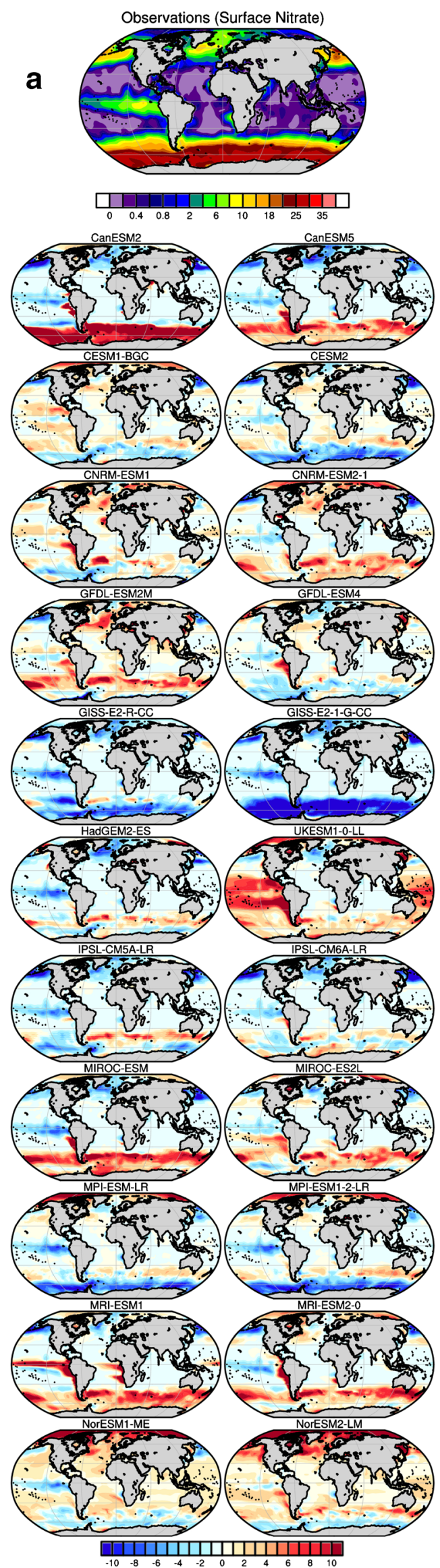

Observations (Surface Silicic Acid)

b
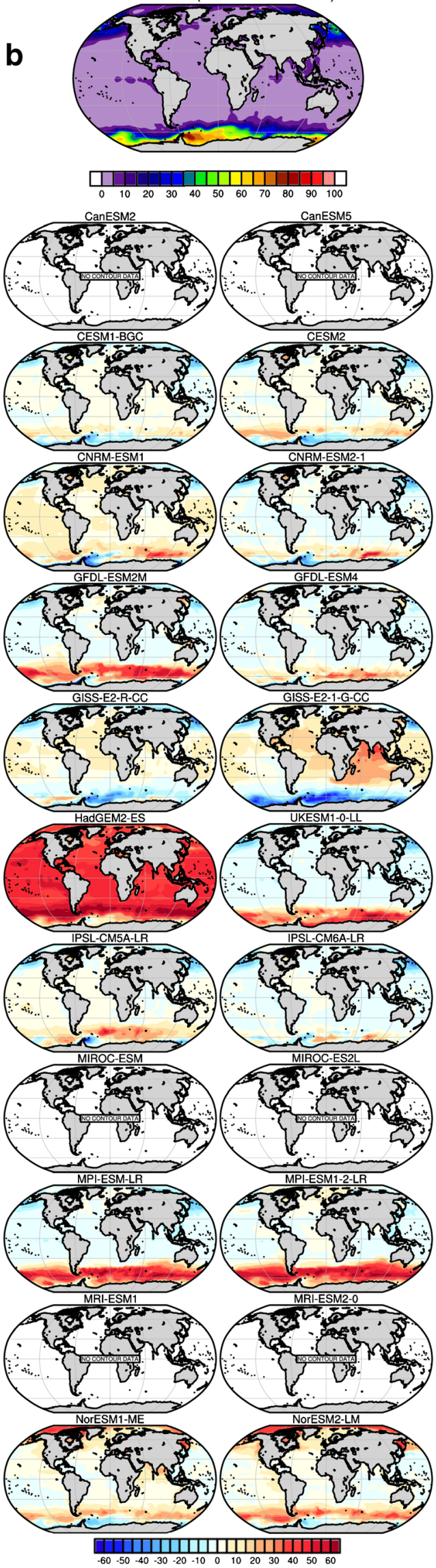

黑 Springer 
Fig. 4 Model-data

intercomparison of oxygen concentrations at $150 \mathrm{~m} \mathrm{(o2,}$ $\mu \mathrm{mol} \mathrm{L}{ }^{-1}$ ) as a proxy for oxygen minimum zones (OMZs) and as simulated by ocean biogeochemical models embedded within CMIP6 Earth system models (on the right column) and within their former version used for CMIP5 (on the left column). The first top panels in $\mathbf{a}$ and $\mathbf{b}$ show the observed oxygen concentrations at $150 \mathrm{~m}$ from the World Ocean Atlas 2013 (Garcia et al. [145]). The other panels in a show oxygen concentrations at $150 \mathrm{~m}$ as simulated by CMIP5 and CMIP6 models averaged over the period 1995-2014, while panels in b show model-data departure averaged over the period 1995-2014 (see Methods in Supplementary materials)

Observations (150 m Oxygen)

a

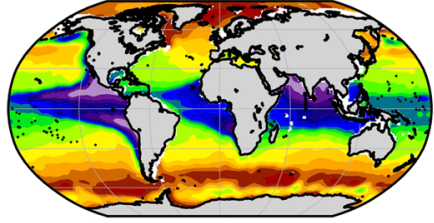

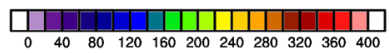
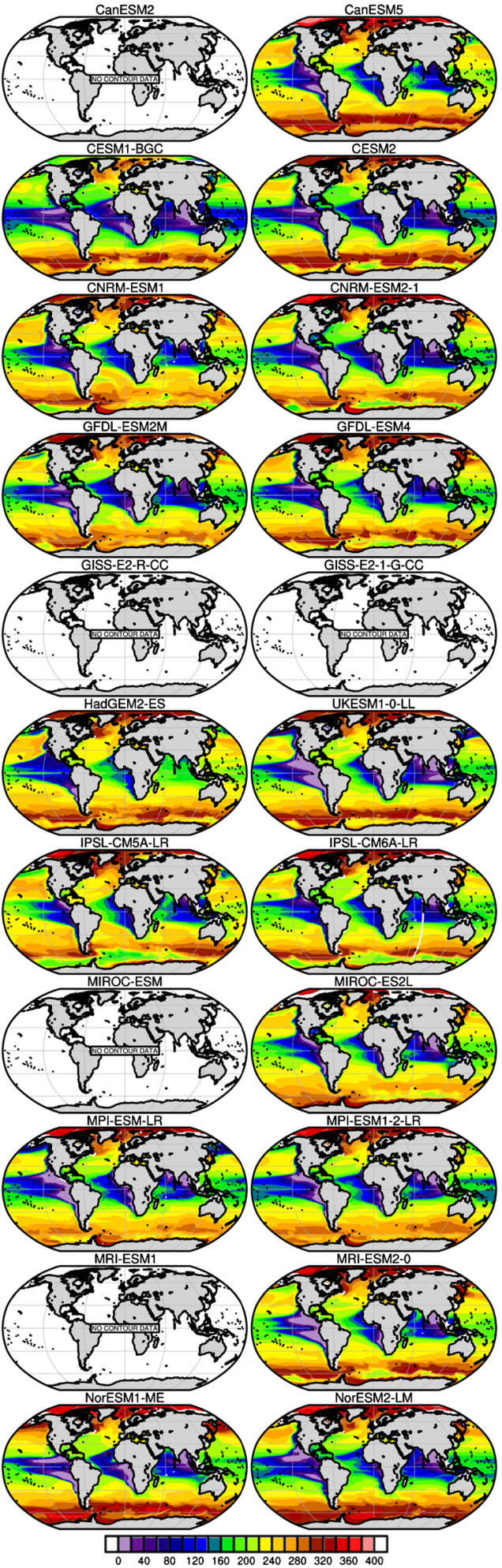

Observations (150 m Oxygen)
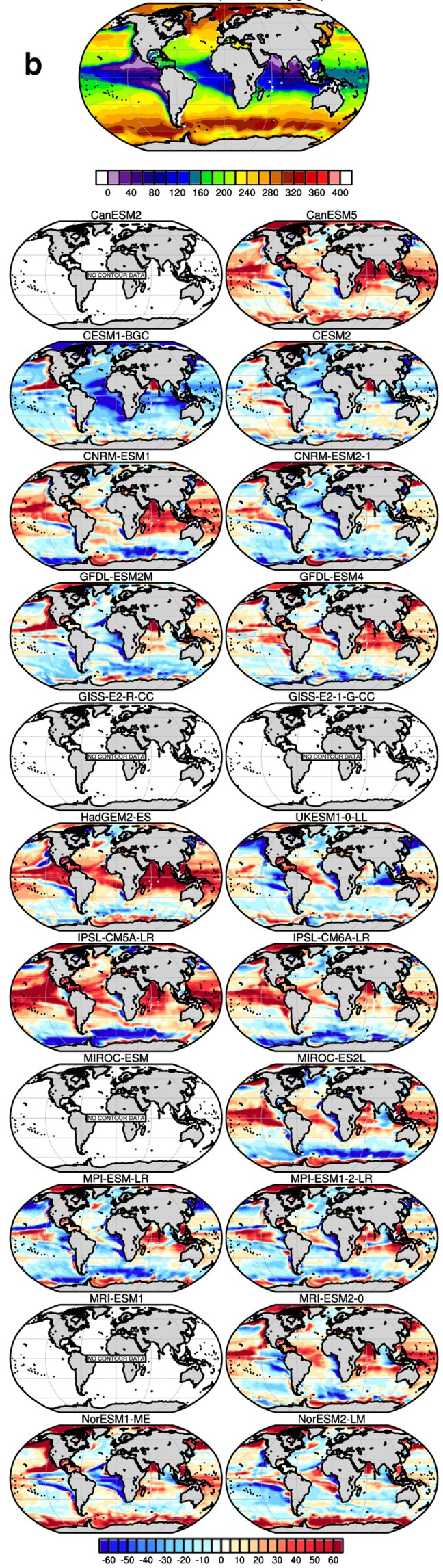

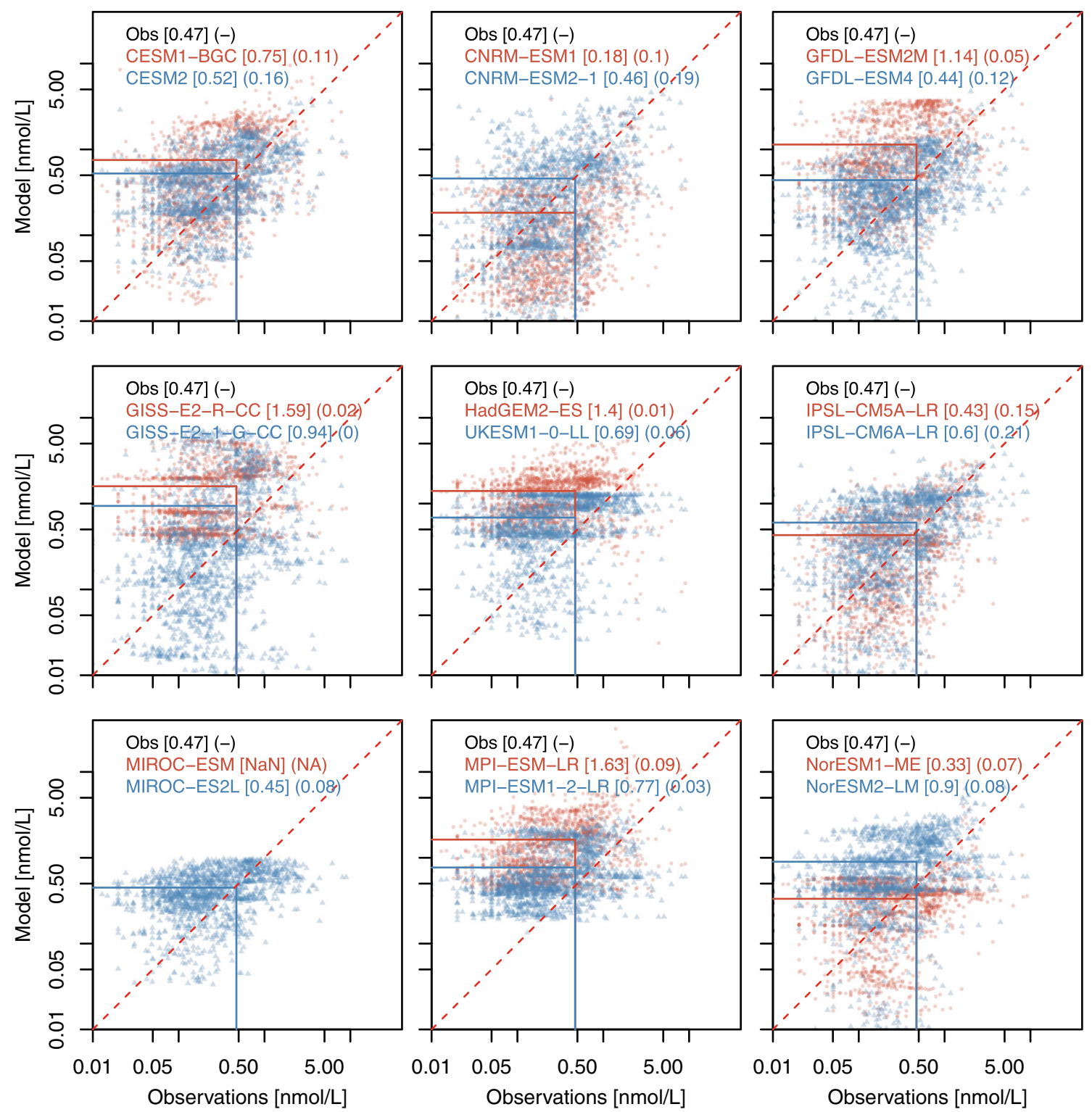

Fig. 5 Model-data scatterplots for surface dissolved iron concentrations (log-log scale). Observational data are derived from the average of the 0 $10 \mathrm{~m}$ of the measurement compilation used in Tagliabue et al. [117]. Model concentrations are taken from the first ocean layer. Red dots and blue triangles indicate CMIP6 and CMIP5 models respectively. The red dashed line shows the 1:1 line; the red and blue solid lines highlight the

model-data mismatch in terms of global mean concentrations for CMIP5 and CMIP6 models (see Methods in Supplementary materials). The global mean for observations and models are given in brackets. Model-data fit (squared correlation, $R^{2}$ ) is given in parenthesis with squared correlation coefficients for CMIP5 and CMIP6 models

diverge in the Southern Ocean [146], where global satellitebased chlorophyll algorithms have been found to significantly underestimate observations [147].

Several CMIP6 models compare more favourably with observations than their CMIP5 predecessors. All models displaying a pattern of generally negative bias in CMIP5 now exhibit large areas of both small positive and small negative biases. Models overestimating surface chlorophyll concentrations in CMIP5 now display reduced biases $(<$ $0.4 \mathrm{mg} \mathrm{Chl} \mathrm{m}{ }^{-3}$ ). This improvement is small for MPI-
ESM1-2-LR, which still overestimates surface concentrations of chlorophyll. Some CMIP6 models, such as CESM2, GISSE2-1-G-CC and NorESM2-LM, display on the contrary larger model-data errors than their predecessors. Given the large diversity across the models, it is difficult to determine whether changes in physical ocean models or changes in ocean biogeochemical models are behind these changes.

However, it is interesting to note that three CMIP6 models (CNRM-ESM 2-1, IPSL-CM6A-LR and UKESM1-0-LL), which share a common ocean physics model, overlap in their 
patterns of positive and negative biases in spite of differences in marine biogeochemistry submodels (spatial correlation of model-data errors $\mathrm{R}^{2}=\sim 0.5$ ).

It is notable that most of the models reviewed here overestimate surface chlorophyll estimates in the Southern Ocean. This bias, however, is likely due in part to the underestimation of Southern Ocean chlorophyll by the global satellite chlorophyll algorithms [147]. The substantial positive Southern Ocean bias in GFDL-ESM 4, for example, is significantly diminished when compared against Johnson's Southern Ocean-specific satellite-based chlorophyll algorithms (e.g. [148]).

Figure $3 \mathrm{a}$ and $\mathrm{b}$ show the distribution of surface nitrate $\left(\mathrm{NO}_{3}\right)$ and silicic acid $\left(\mathrm{H}_{4} \mathrm{SiO}_{4}\right)$, which are represented in both CMIP5 and CMIP6 models. Figure 3 a shows that only GFDL, IPSL and MIROC models have consistently improved their mean states between CMIP5 and CMIP6 for nitrate concentrations. In some cases, model generations show the same spatial patterns of biases, while others, most noticeably UKESM1-0-LL (where entirely new marine biogeochemistry has been incorporated), show a large overestimation of surface nitrate concentration over the tropics.

A comparison of simulated surface concentrations of silicic acid with modern observations shows that all models except GISS and CESM models have improved their representation of the surface distribution of silicic acid (Fig. 3b). The most striking improvement is seen between HadGEM2-ES and UKESM1-0-LL. Such an improvement is explained by the switch in the biogeochemical model component between CMIP5 and CMIP6, from Diat-HadOCC to MEDUSA-2.0 (see [96], for further details). Figure $3 \mathrm{~b}$ sheds light upon another systematic bias in the Southern Ocean where all the models display large model-data errors independent of their generation. It suggests that processes other than ocean resolution or the complexity of the marine biogeochemical model may be at the origin of this systematic model deficiency. The pattern of error differs among models. UKESM1-0-LL, MPIESM 1-2-LR and GISS-E2-1-G-CC display a uniform bias in simulated silicic acid concentrations, whereas all the other models show a mixture of positive and negative biases in simulated concentrations.

Figure 4 a presents the pattern of oxygen concentrations at a depth of $150 \mathrm{~m}$ where the signature of the oxygen minimum zone (OMZ) is expected to be visible. Note that 9 of 12 models simulated $\mathrm{O}_{2}$ in CMIP5, and one further model added $\mathrm{O}_{2}$ for CMIP6.

In general, CMIP6 models improve upon their CMIP5 predecessors in their representation of oxygen at $150 \mathrm{~m}$ (Fig. 4b). Model errors in the Southern Ocean have been reduced in CMIP6 with respect to CMIP5, highlighting a better representation of the deep ocean ventilation in the Southern Ocean or more accurate biogeochemical characteristics of outcropping water masses. Model-data errors have also been reduced in
CMIP6 in large domains of the Indian Ocean where large OMZs occur although all models display a systematic overestimation of oxygen at $150 \mathrm{~m}$ in the Arabian Sea. The same feature is also observed in the tropical Pacific where a modeldata error has been reduced in CMIP6 with respect to CMIP5. Contrasting with the other ocean domains, models' performance has not improved in the Atlantic Ocean. For example, in the tropical Atlantic, some models have shifted in the sign of the model-data errors: from a negative bias in CMIP5 (stronger-than-observed OMZ) to a positive bias in CMIP6 (weaker-than-observed OMZ) or the opposite. In both cases, the absolute magnitude of the model-data errors in this region remains similar between model generations. This implies a systematic bias in ocean biogeochemical models which seems independent from ocean resolution or complexity of marine biogeochemistry models. Besides, our review of model performance highlights that open ocean hypoxia remains poorly represented in ocean biogeochemical models; the CMIP6 models still tend to overestimate this marine biogeochemical feature with respect to their CMIP5 predecessors. This is especially clear in the southern tropical Pacific, where all models except CESM2 and GFDL-ESM 4 overestimated the level of hypoxia of the OMZ (Fig. 4).

Improvement in GFDL-ESM 4 is explained by a suite of updates and changes in model physics (i.e. mixing and Southern Hemisphere climate) and biogeochemical parameterizations (i.e. the use of a revised remineralization scheme for organic matter depending on oxygen and temperature of Laufkötter et al. [148]). In addition, COBALTv2 has lower net primary productivity than TOPAZv2 which allows the highnutrient low-chlorophyll region to spread further meridionally in the tropical Pacific and reduce the eastern equatorial nutrient trapping and associated oxygen decline.

The surface distribution of dissolved iron is also an important feature of marine biogeochemistry. Its availability controls marine biological production in several ocean regions [149]. As for oxygen, Table 1 highlights that marine iron cycling is not represented in all biogeochemical models. Nonetheless, this number has increased in CMIP6 (Table 1). It translates the current scientific consensus which recognizes the need to resolve the iron cycling in biogeochemical model in order to better simulate the marine biogeochemical dynamics, e.g. for glacial-interglacial climate change [150] or for variability and response to climate change [151].

Figure 5 illustrates, however, that the performance of the current generation of models with respect to iron does not improve much with respect to that of the previous generation. Indeed, the model-data fit estimated with squared correlation coefficients remains $<0.25$. This fit has not progressed much from CMIP5 to CMIP6, except possibly for IPSL and CNRM models which both employed PISCESv1 [40, 41] for CMIP5 and PISCESv2 [91] for CMIP6. As highlighted in Aumont 
et al. [91], PISCESv2 includes a more detailed representation of the ocean iron cycle compared with PISCESv1.

The poor agreement between the observed and simulated distribution of dissolved iron relative to macronutrients (Fig. 3) partly reflects differences in the nature of the datasets. The relatively large number of nitrate measurements globally, for example, has allowed construction of robust climatological patterns [145] that model climatologies can be compared against. The relative paucity of dissolved iron measurements, in contrast, requires a comparison of modelled climatologies against patchy individual measurements. Despite this, Fig. 5 shows that some CMIP6 models better simulate the global average concentration of dissolved iron than their predecessors. This is particularly clear for UKESM1-0-LL, MPI-ESM 1-2-LR and GFDL-ESM 4. It is interesting to see the various modelling approaches for representing marine iron cycling. UKESM1-0-LL and MIROC-ES2L, for instance, use respectively Dutkiewicz et al. [152] and Moore and Braucher [153] parameterization for marine iron cycling that removes dissolved iron concentrations above an ad hoc threshold. Other ocean biogeochemical models use mechanistic iron cycling schemes that avoid the needs of ad hoc thresholds (e.g. PISCES-v2 and PISCES-v2-gas employs Völker and Tagliabue [154] formulation and TOPAZv2 applies an empirical relationship to dissolved organic carbon (DOC) to derive ligand concentrations).

Table 4 provides a large-scale picture of the model's ability to simulate key downward biogeochemical fluxes involved in global carbon and nutrients cycling. Most of the CMIP6 marine biogeochemical models better simulate the magnitude of the surface and $100 \mathrm{~m}$ biogeochemical fluxes than their CMIP5 predecessors. Indeed, CESM2, CNRM-ESM2-1, GISS-E2-1-G-CC, IPSL-CM6A-LR, MPI-ESM 1-2-LR and NorESM2-LR have improved the representation of at least one biogeochemical fluxes with respect to their CMIP5 predecessors; BCC-CSM2-MR, CanESM5, GFDL-ESM 4 and MIROC-ES2L display comparable performance; only CanESM5-CanOE, MRI-ESM 2-0 and NorESM2-LM have respectively degraded the representation of either the vertically integrated net primary productivity or the carbon export at 100 m compared with their CMIP5 predecessors.

Despite the general improvement, Table 4 highlights that several CMIP6 models fall outside the range of remotesensing estimates of primary production $([157,158,161])$. It suggests that the current generation of marine biogeochemical models still has difficulties to model underlying processes involved in the carbon fixation by phytoplankton (such as nutrient colimitation, nitrogen fixation, remineralization), required to accurately simulate the magnitude of the vertically integrated net primary productivity. At the same time, it is also important to acknowledge that there are still large uncertainties in remote-sensing-based estimates of primary production, e.g. 38.8-42.1 $\mathrm{Pg} \mathrm{C}$ year $^{-1}$ in the most recent estimates of
Kulk et al. [158] and 47.5-52.1 $\mathrm{Pg} \mathrm{C}_{\text {year }}{ }^{-1}$ according to Behrenfeld et al. [157].

Figures 6 and 7 track changes in performance between CMIP5 and CMIP6 marine biogeochemical models. Figure 6 highlights how far the CMIP6 models have improved their capability to simulate observed spatial patterns with respect to their CMIP5 predecessors; Fig. 7 summarizes the overall model performance including information on model performance to reproduce observed distribution (pattern and magnitude).

Both Figs. 6 and 7 show that CMIP6 models have improved the representation of the ocean physics (here the ocean mixed-layer depth). The cross-generation picture of the model performance for marine biogeochemistry is more contrasted. Globally, Figs. 6 and 7 show that most of the CMIP6 models outcompete their CMIP5 predecessors. However, this improvement remains modest. Except for some models displaying a noticeable improvement for one or two biogeochemical fields (surface nitrate for CESM2, surface chlorophyll for CNRM-ESM2-1, surface silicic acid for GFDLESM 4), most of the CMIP6 model display a slight increase in model-data spatial correlation (up to +0.2 , Fig. 6) or an overall reduction in model-data RMSE of about $20 \%$ (Fig. 7). Besides, this improvement does not concern all models. For instance, GISS-E2-1-G-CC shows a noticeable degradation in performance for all of the biogeochemical fields analyzed here.

\section{Conclusions}

\section{Summary of 5 Years of Ocean Biogeochemical Model Development}

Our review of available Earth system models highlights that the current generation of marine biogeochemical models used for CMIP6 displays a greater diversity than the previous one used for CMIP5. Several marine biogeochemical models have evolved toward a more comprehensive representation of marine biogeochemistry (i.e. CESM, CNRM, GFDL, IPSL, MIROC, UKESM), typically including an expanded array of biological taxa (e.g. diazotrophs) or elemental cycling (e.g. oxygen and iron cycles), variable stoichiometry, sediments (e.g. sediment box module) and the representation of (non$\mathrm{CO}_{2}$ ) trace gases relevant to atmospheric chemistry. On the opposite, some groups have limited the increase in model complexity between CMIP5 and CMIP6 (i.e. BCC, GISS, MPI, MRI, NorESM). Finally, it is interesting to note that some groups have started to investigate the use of reduced complexity marine biogeochemical model (i.e. GFDL) or to intercompare in a traceable framework the impact of rising complexity on the simulated marine biogeochemistry (CanESM). 
Table 4 Comparison between observational and model estimates of biogeochemical fluxes over the modern period. For both CMIP5 and CMIP6 models, biogeochemical fluxes are calculated over the 1995-2014 period (see Methods in Supplementary materials)

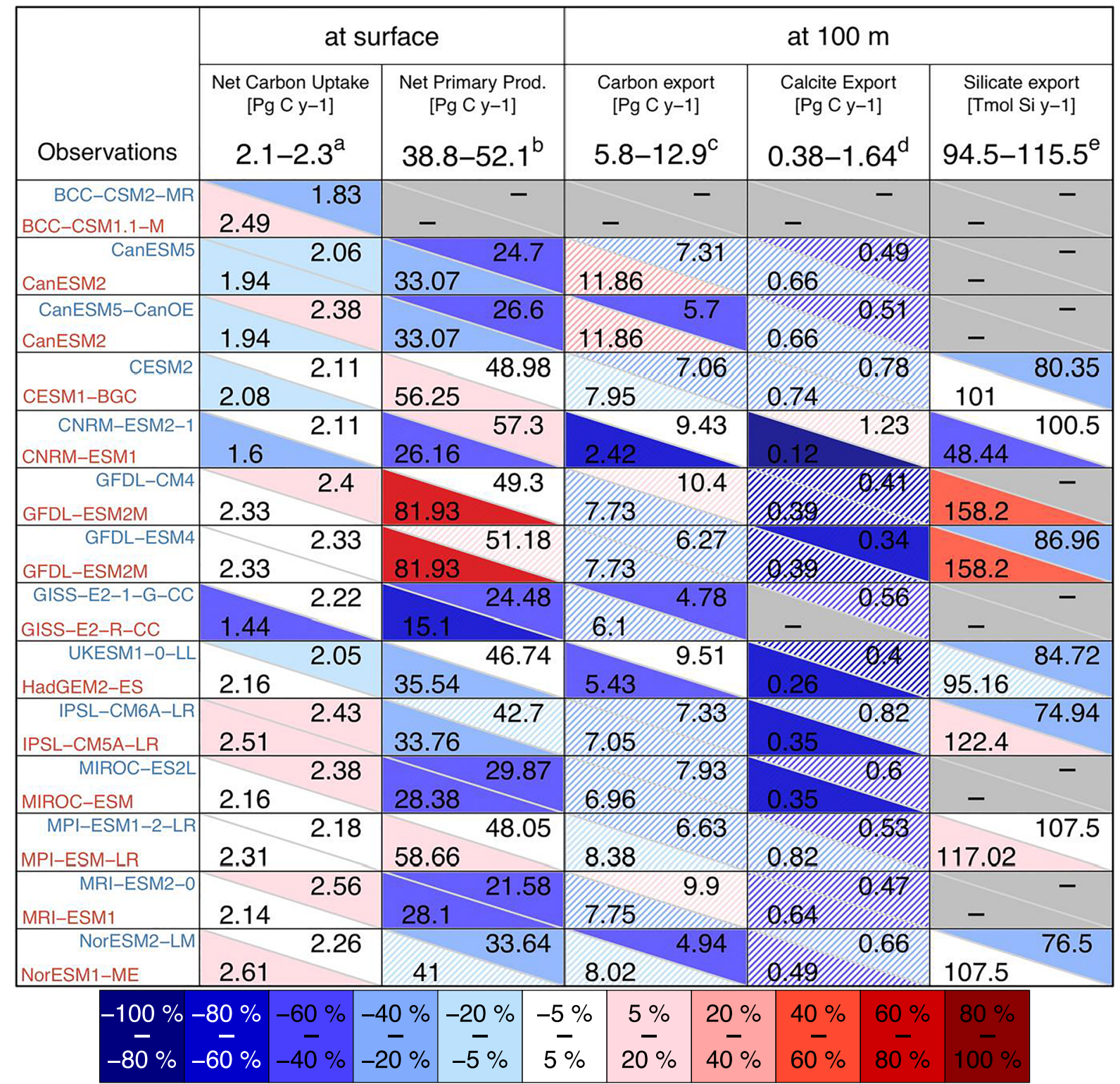

Observational estimates are derived from the following database: ${ }^{a}$ Landschützer et al. [143] product average over 1995-2014 and adjusted for the preindustrial ocean source of $\mathrm{CO}_{2}$ from river input to the ocean consistently with the methodology employed in [155] that used a river flux adjustment of $0.78 \mathrm{Pg} \mathrm{C}_{\text {year }}{ }^{-1}$ [156]; ${ }^{\mathrm{b}}$ maximal range of remote-sensing estimates from Behrenfeld et al. [157] and Kulk et al. [158]; ${ }^{\mathrm{c}}$ Dunne et al. [159] and ${ }^{\mathrm{d}}$ Tréguer and De La Rocha [160]. When required, the modelled net ocean carbon uptake is corrected with the net riverine-induced outgassing diagnosed from the piControl simulation. Coloured cells indicate the relative deviation in model global estimates with respect to the observation median best estimates; hatched coloured cells indicate where model global estimates fall within the observational uncertainty range. Grey cells indicate missing or unrepresented biogeochemical fluxes

When assessed against observations, most of the CMIP6 models generally outperform their CMIP5 predecessors in many regions and for most of the marine biogeochemical fields reviewed here (Figs. 6 and 7 and Table 4). However, this model review has also highlighted several systematic model-data errors that are persistent even in CMIP6 models (e.g. oxygen concentrations at $150 \mathrm{~m}$ in tropical Atlantic, nutrient trapping in the Southern Ocean).

Our review also shows that the modelling approaches have evolved between CMIP5 and CMIP6. Indeed, most modelling groups have spun-up their model over a longer period for CMIP6 with respect to CMIP5 in order 

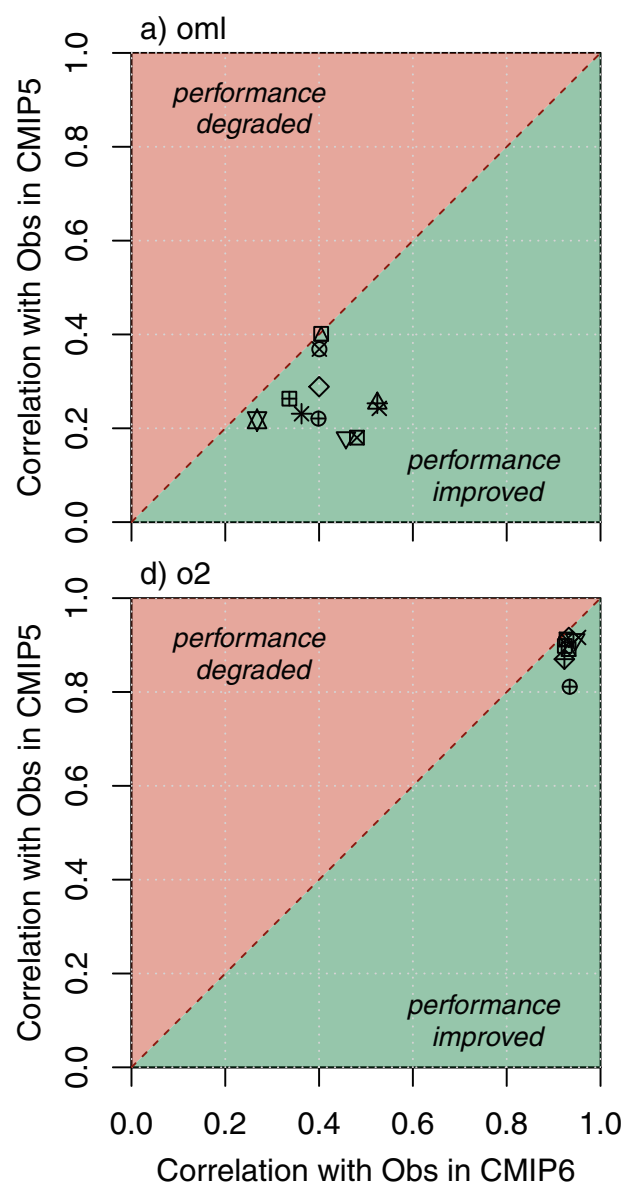

O BCC-CSM2-MR vs. BCC-CSM1.1-M

$\triangle$ CanESM5 vs. CanESM2

+ CanESM5-CanOE vs. CanESM2

$\times$ CESM2 vs. CESM1-BGC

$\diamond$ CNRM-ESM2-1 vs. CNRM-ESM1 b) fgco2

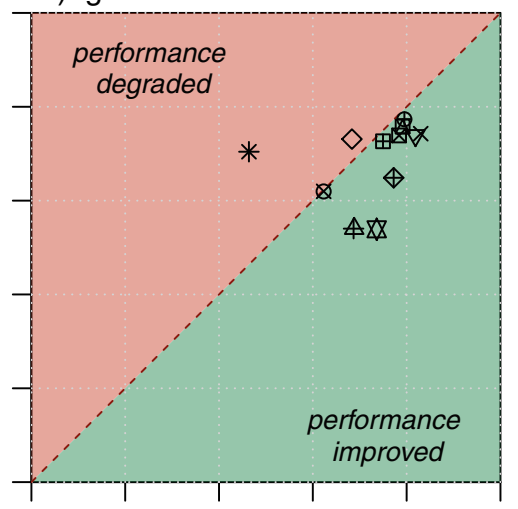

e) no3

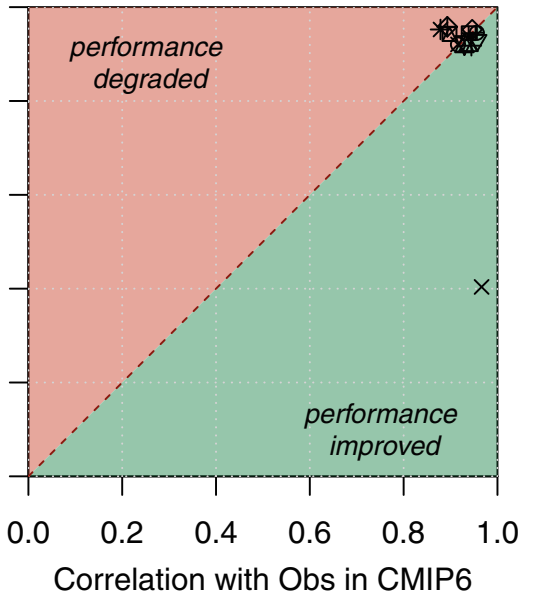

$\nabla$ GFDL-ESM4 vs. GFDL-ESM2M

$\otimes$ GFDL-CM4 vs. GFDL-ESM2M

* GISS-E2-1-G-CC vs. GISS-E2-R-CC

$\oplus$ UKESM1-0-LL vs. HadGEM2-ES

$\oplus$ IPSL-CM6A-LR vs. IPSL-CM5A-LR c) chl

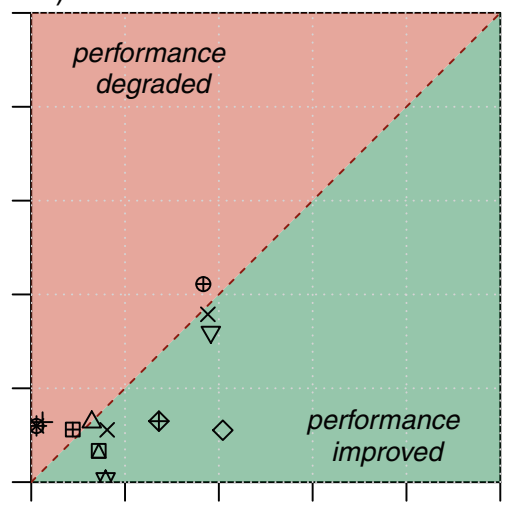

f) $\mathrm{si}$

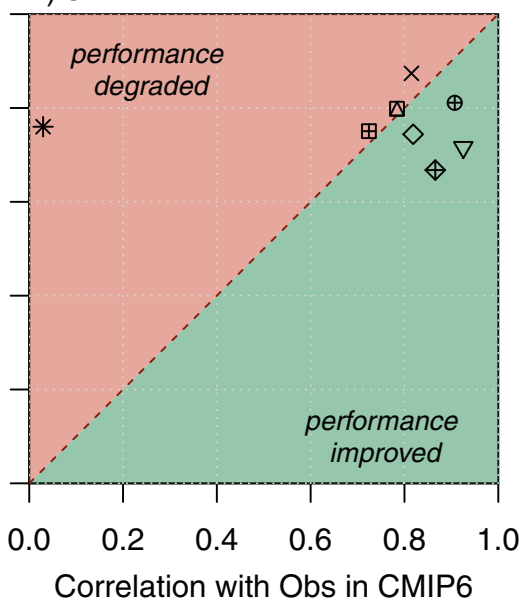

$\$$ MIROC-ES2L vs. MIROC-ESM

$\rightarrow$ MPI-ESM1-2-LR vs. MPI-ESM-LR

MRI-ESM2-0 vs. MRI-ESM1

凶 NorESM2-LM vs. NorESM1-ME
Fig. 6 Scatter plot confronting the performance of CMIP6 models to replicate the geographical structure of observed fields with respect to that of their CMIP5 predecessors. The performance metrics are the model-data spatial correlation computed from yearly averaged data and model outputs. The variables of interest are mixed-layer depth (oml), airsea $\mathrm{CO}_{2}$ flux (fgco2), surface chlorophyll (chl), oxygen concentration at $150 \mathrm{~m}$ (o2) and surface concentrations of nitrate (no3) and silicic acid (si).
The green (red) shading flags an improvement (degradation) of the model performance to replicate the observed geographical structure for a given field. The ocean mixed-layer depth is computed similarly in all models; it is based on a density criterion of $0.03 \mathrm{~kg} \mathrm{~m}^{-3}$. The ocean mixed-layer depth simulated by the various Earth system models is evaluated against the observational dataset of de Boyer Montégut et al. [162]

performance is not the only mean to understand multi-model uncertainty, comparisons against seasonal to multi-annual variations in observed quantities may ultimately prove most critical to building confidence in future climate projections (e.g. $[13,163])$.

\section{What's Next?}

In this final section, we identify some directions where marine biogeochemical models could continue to improve or to progress. 


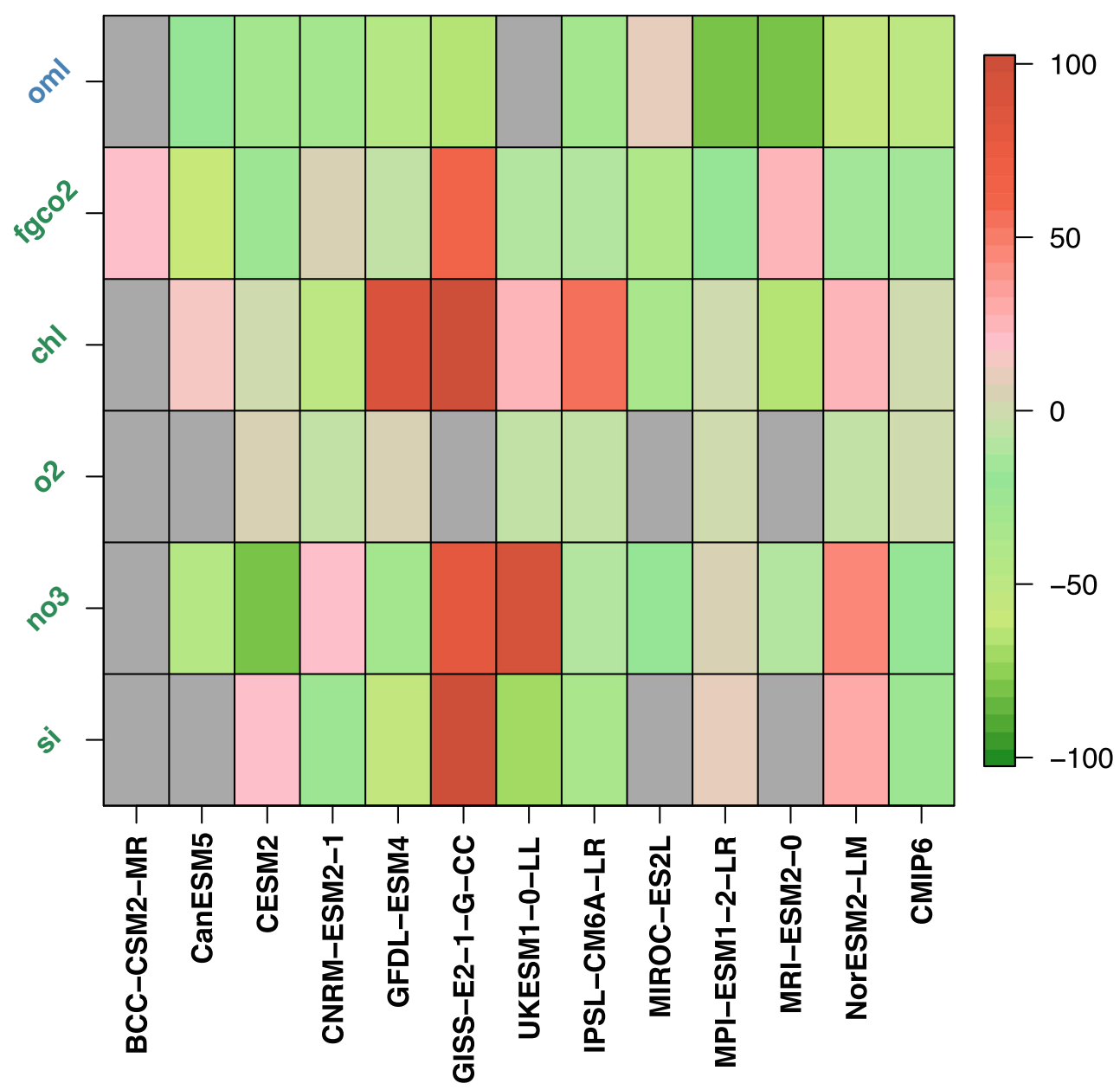

Fig. 7 Portrait diagram highlighting the performance of CMIP6 models (one representative per modelling groups) with respect to their CMIP5 predecessors. The variables of interest are mixed-layer depth (oml), airsea $\mathrm{CO}_{2}$ flux (fgco2), surface chlorophyll (chl), oxygen concentration at $150 \mathrm{~m} \mathrm{(o2)}$ and surface concentrations of nitrate (no3) and silicic acid (si). The skill score metric, Z-score, is computed for a given model and for a given field as follows: Z-score $=\frac{\operatorname{RMSE}_{\mathrm{CMPP}}(M)-\operatorname{RMSE}_{\mathrm{CMIP}}(P)}{\operatorname{RMSE} \mathrm{CMIPS}_{\text {CM }}(P)} \times 100$, where $\operatorname{RMSE}_{\mathrm{CMIP6}}(M)$ is the global area-weighted average model-data rootmean-squared error (RMSE) of the model of the current generation contributing to CMIP6 and $\mathrm{RMSE}_{\mathrm{CMIP} 5}(P)$ is the RMSE of its predecessor

The first step change to expect in the next generation of models is the emergence of high-resolution ocean biogeochemical models fit to investigate centennial-scale simulation. This step change may be supported in a number of ways: (1) the availability of greater computational resources; (2) the use of hybrid-resolution numerical schemes to decrease the cost of biogeochemical models (e.g. [164]); (3) actually reduced complexity of marine biogeochemical models (e.g. such as miniBLING; [105]); (4) the use of machine learning to either accelerate marine biogeochemical models or to reduce the numerical cost necessary to improve their performance (i.e. via tuning). These (and potentially other) step changes will help to understand the extent to which mesoscale or sub-mesoscale ocean physics might change the response of marine biogeochemistry to rising $\mathrm{CO}_{2}$ and

that has contributed to CMIP5. Greenish (reddish) colours and negative (positive) Z-scores indicate improved (degraded) field representations in CMIP6 model versions; darker colours indicate a greater change from CMIP5 to CMIP6. Grey indicates missing data for one or both generations of models. Air-sea $\mathrm{CO}_{2}$ flux (fgco2) was adjusted for riverineinduced outgassing as in Table 4. The ocean mixed-layer depth is computed similarly in all models; it is based on a density criterion of $0.03 \mathrm{~kg} \mathrm{~m}^{-3}$. The ocean mixed-layer depth simulated by the various Earth system models is evaluated against the observational dataset of de Boyer Montégut et al. [162]

climate change - a missing factor in such models already highlighted from CMIP5 and IPCC AR5 [2].

A second important step change is related to the phytoplankton physiology and evolution. This change may have two benefits. First, several recent studies show that the inclusion of a more comprehensive treatment of plankton physiology may improve model performance, in particular some systematic biases in the Southern Ocean (e.g. $[108,165])$. Then, this improvement is arguably a first step toward the representation of adaptation and fitness in ocean biogeochemical models [166, 167]. This omission remains an important caveat for multi-stressors studies (e.g. [9]) or time-of-emergence studies [168] as current models effectively assume no change in the underlying properties of modelled plankton. 
Future developments should be pursued in the context of the internal cycling of micronutrients involved in phytoplankton physiology and metabolism such as iron, zinc or copper. Our review confirms that the current generation of marine biogeochemical models are still struggling to reproduce the major features of the oceanic iron distribution although the observations of dissolved iron in the ocean are growing rapidly [149] and are made widely available by GEOTRACES [169]. A key challenge for iron is that the dissolved iron commonly measured only appears to represent a trace residual of the underlying fluxes [170], pointing to the need for more process studies and observations of fluxes. It is possible that iron isotopes may yield further insight into the role of external inputs and internal cycling in shaping iron distributions in the observations and models. Finally, the development of additional model components dealing with other trace metals, such as cobalt [171], zinc [172], manganese [173] and copper [174], may also prove beneficial in constraining the magnitude and dynamics of external inputs in particular.

An expanded array of biological taxa may also be expected in the next generation of ocean biogeochemical models. A potentially important change in the ocean ecosystem modelling paradigm is the inclusion and integration of mixotrophs which are an important grazer of bacterioplankton, and which also feed on phytoplankton, microzooplankton and (sometimes) mesozooplankton. Mixotrophic bacterivory among the phytoplankton may be important for alleviating nutrient stress and may increase primary production in oligotrophic waters. Some modelling studies indicate that mixotrophy has a profound impact on marine planktonic ecosystems and may enhance primary production, biomass transfer to higher trophic levels and the functioning of the biological carbon pump [175].

This expanded array of biological taxa may take the concept of the marine biogeochemical model up to the marine ecosystem model, which will enable the representation of feedbacks of the marine trophic food web on marine biogeochemical cycles. The work of Lefort et al. [57] provides an example of this type of marine ecosystem model realizing a comprehensive coupling between a marine biogeochemical model (PISCES) with a marine trophic food web model (APECOSM).

A third important step change is related to the couplings between Earth system components and ocean biogeochemistry. Our review highlights that models have evolved toward a more comprehensive treatment of biological boundary conditions (e.g. atmospheric deposition, riverine inputs, sediments, ice sheets, geothermal sources) but that these latter are currently largely represented using climatological data rather than dynamic connections. Progress toward more complete couplings between Earth system components such as rivers, ice sheet/iceberg calving and ice shelves or atmospheric aerosols can help to better simulate interactions between marine biogeochemistry, biogeochemical cycles and climate.

In the same manner, a more comprehensive treatment of biophysical and biogeochemical feedback could be realized in the next generation of marine biogeochemical models. The latter involves, for instance, ocean emissions of greenhouse gases or biogenic volatile organic compounds (BVOCs) that are already simulated by a small number of models (see Table 5). However, our understanding of the global cycles of DMS, $\mathrm{N}_{2} \mathrm{O}$ and $\mathrm{CH}_{4}$ (including, specifically, the processes that produce them) is much less developed compared with $\mathrm{CO}_{2}$. Therefore, better treatment of biophysical and biogeochemical feedback requires a larger array of observational data sets in order to improve our understanding of the processes underlying these ocean emissions.

From the perspective of tracking future model improvement, it is important to stress that our capacity to assess model performance resulting from any of the potential advances discussed above is contingent upon continued improvement in observational constraints. Existing constraints were adequate for detecting large skill differences between CMIP5 and CMIP6 models, but the overall improvement in models necessitates more precise comparisons to detect skill differences. Such comparisons are challenged by data sparsity and

Table 5 Ocean natural emissions of non- $\mathrm{CO}_{2}$ trace gases simulated by CMIP6 models

\begin{tabular}{|c|c|c|c|}
\hline & DMS (Tg S year ${ }^{-1}$ ) & $\mathrm{N}_{2} \mathrm{O}\left(\operatorname{Tg~N}\right.$ year $\left.^{-1}\right)$ & NHx $\left[\right.$ Tg N year ${ }^{-1}$ ) \\
\hline Observational estimates & $17.6-34.4^{\mathrm{a}}$ & $1.9-9.4^{\mathrm{b}}$ & $2-5^{\mathrm{c}}$ \\
\hline CNRM-ESM 2-1 & 24.38 & 3.97 & - \\
\hline GFDL-ESM 4 & - & - & 3.10 \\
\hline UKESM1-0-LL & 16.19 & - & - \\
\hline MIROC-ES2L & 18.46 & 4.31 & - \\
\hline MPI-ESM 1-2-LR & - & 8.89 & - \\
\hline NorESM2-LM & 20.0 & - & - \\
\hline
\end{tabular}

${ }^{\mathrm{a}}$ Lana et al. [176]; ${ }^{\mathrm{b}}$ Buitenhuis et al. [177]; ${ }^{\mathrm{c}}$ Paulot et al. [178] 
uncertainties in algorithms designed to derive global fields from sparse data or infer properties of interest from remotely sensed variables. Continued improvement in the quality and quantity of data-based constraints is critical.

That being said, our review of the available pairs of CMIP5-CMIP6 marine biogeochemical models strongly suggests that careful consideration is needed when selecting model complexity with regard to the fitness-for-purpose of models (i.e. carbon cycle feedbacks, multiple Earth system feedbacks, multi-stressors, adaptation and biodiversity). Indeed, when confronting model complexity against model mean state performance, our work suggests that complex models do not necessarily outperform simple models. This is consistent with the earlier study of Kwiatkowski et al. [179], which directly led to the choice of marine biogeochemistry model in UKESM1-0-LL, where across many Earth system relevant metrics, the simplest model performed best. In this sense, our review shows that simple models (e.g. OCMIP nutrient restoring or NPZD type) remain viable when investigating carbon cycle feedbacks, although more complex models do still permit a better linkage with the marine biodiversity or a broader array of feedbacks and potentially more realistic Earth system behaviour.

Acknowledgements R.S. on behalf of the author team thank the two anonymous referees for their useful comments that have improved the quality of this paper. R.S. thanks the author team for their contributions to this paper that occurred during the coronavirus SARS-CoV-2 pandemic. R.S. and S.B. thank the support of the team in charge of the CNRM-CM climate model. Supercomputing time was provided by the Météo-France/ DSI supercomputing center.

Funding Information This work was supported by the European Union's Horizon 2020 research and innovation program with the CRESCENDO project under the grant agreement No 641816, the TRIATLAS project under the grant agreement No 817578 and the COMFORT project under the grant agreement No 820989. JS and JT were supported by the Research Council of Norway through the projects INES (grant no. 270061) and COLUMBIA (grant no 275268). LK was supported by the Agence Nationale de la Recherche (grant no. ANR-18ERC2-0001-01)

\section{Compliance with Ethical Standards}

Conflict of Interest On behalf of all authors, the corresponding author states that there is no conflict of interest.

Human and Animal Rights This article does not contain any studies with human or animal subjects performed by any of the authors.

Disclaimer This article reflects only the authors' view - the funding agencies as well as their executive agencies are not responsible for any use that may be made of the information that the article contains.

Open Access This article is licensed under a Creative Commons Attribution 4.0 International License, which permits use, sharing, adaptation, distribution and reproduction in any medium or format, as long as you give appropriate credit to the original author(s) and the source, provide a link to the Creative Commons licence, and indicate if changes were made. The images or other third party material in this article are included in the article's Creative Commons licence, unless indicated otherwise in a credit line to the material. If material is not included in the article's Creative Commons licence and your intended use is not permitted by statutory regulation or exceeds the permitted use, you will need to obtain permission directly from the copyright holder. To view a copy of this licence, visit http://creativecommons.org/licenses/by/4.0/.

\section{References}

1. Sarmiento JL, Gruber N. Ocean biogeochemical dynamics: Princeton University Press; 2006. p. 67. http://www.mendeley. com/research/chapter-10-carbon-cycle-co2-climate/.

2. Ciais $\mathrm{P}$, et al. Carbon and other biogeochemical cycles. Clim Chang 2013 - Phys Sci Basis. 2013:465-570. https://doi.org/10. 1017/CBO9781107415324.015.

3. Lengaigne M, Madec G, Bopp L, Menkes C, Aumont O, Cadule P. Bio-physical feedbacks in the Arctic Ocean using an Earth system model. Geophys Res Lett. 2009;36:L21602. https://doi. org/10.1029/2009GL040145.

4. Roy $\mathrm{T}$, et al. Regional impacts of climate change and atmospheric $\mathrm{CO} 2$ on future ocean carbon uptake: a multimodel linear feedback analysis. J Clim. 2011;24:2300-18. https://doi.org/10.1175/ 2010JCLI3787.1.

5. Schwinger J, et al. Nonlinearity of ocean carbon cycle feedbacks in CMIP5 earth system models. J Clim. 2014;27:3869-88. https:// doi.org/10.1175/JCLI-D-13-00452.1.

6. Chassot E, Bonhommeau S, Dulvy NK, Mélin F, Watson R, Gascuel D, et al. Global marine primary production constrains fisheries catches. Ecology Letters. 2010;13:495-505. https://doi. org/10.1111/j.1461-0248.2010.01443.x.

7. Ryther JH. Photosynthesis and fish production in the sea. Science. 1969;166:72-6. https://doi.org/10.1126/science.166.3901.72.

8. Stock CA, John JG, Rykaczewski RR, Asch RG, Cheung WW, Dunne JP, et al. Reconciling fisheries catch and ocean productivity. Proc Natl Acad Sci. 2017;114(8):E1441-9. https://doi.org/10. 1073/pnas.1610238114.

9. Bopp L, et al. Multiple stressors of ocean ecosystems in the 21st century: projections with CMIP5 models. Biogeosciences. 2013;10:6225-45. https://doi.org/10.5194/bg-10-6225-2013.

10. Cocco V, et al. Oxygen and indicators of stress for marine life in multi-model global warming projections. Biogeosciences. 2013;10:1849-68. https://doi.org/10.5194/bg-10-1849-2013.

11. Doney SC, et al. Climate change impacts on marine ecosystems. Annu Rev Mar Sci. 2012;4:11-37. https://doi.org/10.1146/ annurev-marine-041911-111611.

12. Gehlen M, Séférian R, Jones DOB, Roy T, Roth R, Barry J, et al. Projected $\mathrm{pH}$ reductions by 2100 might put deep North Atlantic biodiversity at risk. Biogeosciences. 2014;11:6955-67.

13. Kwiatkowski L, Orr JC. Diverging seasonal extremes for ocean acidification during the twenty-first century. Nat Clim Chang. 2018;8:141-5. https://doi.org/10.1038/s41558-017-0054-0.

14. Orr JC, et al. Anthropogenic ocean acidification over the twentyfirst century and its impact on calcifying organisms. Nature. 2005;437:681-6. https://doi.org/10.1038/nature04095.

15. Tagliabue BL, Gehlen M. The response of marine carbon and nutrient cycles to ocean acidification: large uncertainties related to phytoplankton physiological assumptions. Glob Biogeochem Cycles. 2011;25:GB3017. https://doi.org/10.1029/ 2010GB003929. 
16. Tynan E. Ocean acidification: emergence from pre-industrial conditions. Nat Geosci. 2016;9:804. https://doi.org/10.1038/ ngeo2834.

17. Hopkins FE, Coauthors. The impacts of ocean acidification on marine trace gases and the implications for atmospheric chemistry and climate. Proc. R. Soc. A Math. Phys. Eng. Sci. 2020;476: 20190769. https://doi.org/10.1098/rspa.2019.0769.

18. Maier-Reimer E, Hasselmann K. Transport and storage of $\mathrm{C} 02$ in the ocean - an inorganic ocean-circulation carbon cycle model. Clim Dyn. 1987;2:63-90.

19. Sarmiento JL, Orr JC, Siegenthaler U. A perturbation simulation of $\mathrm{CO} 2$ uptake in an ocean general circulation model. J Geophys Res. 1992;97:3621-45. https://doi.org/10.1029/91JC02849.

20. Orr JC, Najjar R, Sabine CL, Joos F. Internal OCMIP Report AHOWTO, Saclay LSCE/CEA. Gif-sur-Yvette, France, 25 pp., 1999.

21. Adachi Y, Yukimoto S, Deushi M, Obata A, Nakano H, Tanaka TY, et al. Basic performance of a new earth system model of the Meteorological Research Institute (MRI-ESM 1). Pap Meteorol Geophys. 2013;64:1-19. https://doi.org/10.2467/mripapers.64.1.

22. Arora VK, Scinocca JF, Boer GJ, Christian JR, Denman KL, Flato $\mathrm{GM}$, et al. Carbon emission limits required to satisfy future representative concentration pathways of greenhouse gases. Geophys Res Lett. $2011 \mathrm{a} ; 38:$ L05805. https://doi.org/10.1029/ 2010GL046270.

23. Bentsen M, Bethke I, Debernard JB, Iversen T, Kirkevåg A, Seland $\varnothing$, et al. The Norwegian Earth System Model, NorESM1-M - Part 1: description and basic evaluation of the physical climate. Geosci Model Dev. 2013a;6:687-720. https:// doi.org/10.5194/gmd-6-687-2013.

24. Dufresne J, Foujols M, Denvil S, et al. Climate change projections using the IPSL-CM5 Earth System Model: from CMIP3 to CMIP5. Clim Dyn. 2013a;40:2123-65. https://doi.org/10.1007/ s00382-012-1636-1.

25. Dunne JP, John JG, Shevliakova E, Stouffer RJ, Krasting JP, Malyshev SL, et al. GFDL's ESM 2 Global Coupled ClimateCarbon Earth System Models. Part II: carbon system formulation and baseline simulation characteristics. J Clim. 2013a;26:224767. https://doi.org/10.1175/JCLI-D-12-00150.1.

26. Giorgetta MA, Jungclaus J, Reick CH, Legutke S, Bader J, Böttinger M, et al. Climate and carbon cycle changes from 1850 to 2100 in MPI-ESM simulations for the Coupled Model Intercomparison Project phase 5. J Adv Model Earth Syst. 2013a;5:572-97. https://doi.org/10.1002/jame.20038.

27. Lindsay K, Bonan GB, Doney SC, Hoffman FM, Lawrence DM, Long MC, et al. Preindustrial-control and twentieth-century carbon cycle experiments with the Earth System Model CESM1(BGC). J Clim. 2014a;27:8981-9005. https://doi.org/10. 1175/JCLI-D-12-00565.1.

28. Romanou A, Gregg WW, Romanski J, Kelley M, Bleck R, Healy $\mathrm{R}$, et al. Natural air-sea flux of $\mathrm{CO}_{2}$ in simulations of the NASAGISS climate model: sensitivity to the physical ocean model formulation. Ocean Model. 2013a;66:26-44. https://doi.org/10.1016/ j.ocemod.2013.01.008.

29. Séférian R, Delire C, Decharme B, Voldoire A. Salas y Melia D, Chevallier M, et al. Development and evaluation of CNRM Earth system model - CNRM-ESM 1. Geosci Model Dev. 2016;9: 1423-53. https://doi.org/10.5194/gmd-9-1423-2016.

30. Watanabe S, Hajima T, Sudo K, Nagashima T, Takemura T, Okajima H, et al. MIROC-ESM 2010: model description and basic results of CMIP5-20c3m experiments. Geosci Model Dev. 2011a;4:845-72. https://doi.org/10.5194/gmd-4-845-2011.

31. Wu T, Li W, Ji J, Xin X, Li L, Wang Z, et al. Global carbon budgets simulated by the Beijing climate center climate system model for the last century. J Geophys Res Atmos. 2013;118: 4326-47. https://doi.org/10.1002/jgrd.50320.
32. Arora VK, et al. Carbon-concentration and carbon-climate feedbacks in CMIP5 earth system models. J Clim. 2013;26:5289-314. https://doi.org/10.1175/JCLI-D-12-00494.1.

33. Arora VK, Katavouta A, Williams RG, Jones CD, Brovkin V, Friedlingstein $\mathrm{P}$, et al. Carbon-concentration and carbon-climate feedbacks in CMIP6 models, and their comparison to CMIP5 models. Biogeosci Discuss. 2020. https://doi.org/10.5194/bg2019-473 in review, 2019.

34. Friedlingstein P, et al. Climate-carbon cycle feedback analysis: results from the $\mathrm{C}^{4}$ MIP Model Intercomparison. J Clim. 2006;19:3337-53. https://doi.org/10.1175/JCLI3800.1.

35. Friedlingstein P, Meinshausen M, Arora VK, Jones CD, Anav A, Liddicoat SK, et al. Uncertainties in CMIP5 climate projections due to carbon cycle feedbacks. J Clim. 2014;27:511-26. https:// doi.org/10.1175/JCLI-D-12-00579.1.

36. MacDougall AH, Gregory J, Stouffer R, Stordal F, Eby M. The oceanic origin of path-independent carbon budgets. Sci Report. 2017;15:124-30. https://doi.org/10.1038/s41598-017-10557-x.

37. Lauvset SK, Tjiputra J, Muri H. Climate engineering and the ocean: effects on biogeochemistry and primary production. Biogeosci Discuss. 2017:1-36. https://doi.org/10.5194/bg-2017235.

38. Plazzotta $\mathrm{M}$, Séférian R, Douville $\mathrm{H}$. Impact of solar radiation modification on allowable $\mathrm{CO}_{2}$ emissions: what can we learn from multi-model simulations? Earth's Futur. 2019. https://doi. org/10.1029/2019EF001165.

39. Tjiputra JF, Grini A, Lee H. Impact of idealized future stratospheric aerosol injection on the large-scale ocean and land carbon cycles. J Geophys Res G Biogeosci. 2016;121:2-27. https://doi.org/ 10.1002/2015JG003045.

40. Aumont O, Bopp L. Globalizing results from ocean in situ iron fertilization studies. Glob Biogeochem Cycles. 2006a;20: GB2017. https://doi.org/10.1029/2005GB002591.

41. Aumont O, Bopp L. Globalizing results from ocean in situ iron fertilization studies. Glob Biogeochem Cycles. 2006b;20: GB2017. https://doi.org/10.1029/2005GB002591.

42. Bertram C. Ocean iron fertilization in the context of the Kyoto protocol and the post-Kyoto process. Energy Policy. 2010;38: 1130-9. https://doi.org/10.1016/j.enpol.2009.10.065.

43. Boyd P. Implications of large-scale iron fertilization of the oceans. Mar Ecol Prog Ser. 2008;364:213-8. https://doi.org/10.3354/ meps07541.

44. de Baar H, Gerringa L, Laan P, Timmermans K. Efficiency of carbon removal per added iron in ocean iron fertilization. Mar Ecol Prog Ser. 2008;364:269-82. https://doi.org/10.3354/ meps07548.

45. Harrison DP. Global negative emissions capacity of ocean macronutrient fertilization. Environ Res Lett. 2017;12:035001. https:// doi.org/10.1088/1748-9326/aa5ef5.

46. Keller DP, Feng EY, Oschlies A. Potential climate engineering effectiveness and side effects during a high carbon dioxideemission scenario. Nat Commun. 2014;5:3304. https://doi.org/ 10.1038/ncomms4304.

47. Yool A, Shepherd JG, Bryden HL, Oschlies A. Low efficiency of nutrient translocation for enhancing oceanic uptake of carbon dioxide. J Geophys Res. 2009;114:C08009. https://doi.org/10.1029/ 2008JC004792.

48. Ferrer-Gonzalez M, Ilyina T, Sonntag S, Schmidt H. Enhanced rates of regional warming and ocean acidification after termination of large-scale ocean alkalinization. Geophys Res Lett. 2018;45: 7120-9. https://doi.org/10.1029/2018GL077847.

49. Gattuso J-P, et al. Ocean solutions to address climate change and its effects on marine ecosystems. Front Mar Sci. 2018;5:337. https://doi.org/10.3389/fmars.2018.00337.

50. González MF, Ilyina T. Impacts of artificial ocean alkalinization on the carbon cycle and climate in Earth system simulations. 
Geophys Res Lett. 2016;43:6493-502. https://doi.org/10.1002/ 2016GL068576.

51. Ilyina T, Wolf-Gladrow D, Munhoven G, Heinze C. Assessing the potential of calcium-based artificial ocean alkalinization to mitigate rising atmospheric $\mathrm{CO} 2$ and ocean acidification. Geophys Res Lett. 2013a;40:5909-14. https://doi.org/10.1002/ 2013GL057981.

52. Ilyina T, Six K, Segschneider J, Maier-Reimer E, Li H, NúñezRiboni I. Global ocean biogeochemistry model HAMOCC: model architecture and performance as component of the MPI-Earth System Model in different CMIP5 experimental realizations. J Adv Model Earth Syst. 2013b;5:287-315. https://doi.org/10. 1029/2012MS000178.

53. John JG, Stock CA, Dunne JP. A more productive, but different, ocean after mitigation. Geophys Res Lett. 2015;42:9836-45. https://doi.org/10.1002/2015GL066160.

54. Schwinger J, Tjiputra J. Ocean carbon cycle feedbacks under negative emissions. Geophys Res Lett. 2018;45:5062-70. https://doi. org/10.1029/2018GL077790.

55. Cheung WWL, Sarmiento JL, Dunne J, Frölicher TL, Lam VWY, Deng Palomares ML, et al. Shrinking of fishes exacerbates impacts of global ocean changes on marine ecosystems. Nat Clim Chang. 2012;3:254-8. https://doi.org/10.1038/nclimate1691.

56. Le Mézo P, Lefort S, Séférian R, Aumont O, Maury O, Murtugudde R, et al. Natural variability of marine ecosystems inferred from a coupled climate to ecosystem simulation. J Mar Syst. 2016;153:55-66. https://doi.org/10.1016/j.jmarsys.2015.09. 004.

57. Lefort S, Aumont O, Bopp L, Arsouze T, Gehlen M, Maury O. Spatial and body-size dependent response of marine pelagic communities to projected global climate change. Glob Chang Biol. 2015a;21:154-64. https://doi.org/10.1111/gcb.12679.

58. Stock CA, et al. On the use of IPCC-class models to assess the impact of climate on living marine resources. Prog Oceanogr. 2011;88:1-27. https://doi.org/10.1016/j.pocean.2010.09.001.

59. Lotze HK, Tittensor DP, Bryndum-Buchholz A, Eddy TD, Cheung WW, Galbraith ED, et al. Global ensemble projections reveal trophic amplification of ocean biomass declines with climate change. Proc Natl Acad Sci. 2019;116(26):12907-12.

60. Tittensor DP, et al. A protocol for the intercomparison of marine fishery and ecosystem models: Fish-MIP v1.0. Geosci Model Dev. 2018;11:1421-42. https://doi.org/10.5194/gmd-11-14212018.

61. Li H, Ilyina T, Muller WA, Sienz F. Decadal predictions of the North Atlantic CO2 uptake. Nat Commun. 2016;7:11076.

62. Li H, Ilyina T, Müller W, Landschützer P. Predicting the variable ocean carbon sink, eaav6471. Sci Adv. 2019;5.

63. Lovenduski NS, Yeager SG, Lindsay K, Long MC. Predicting near-term variability in ocean carbon uptake. Earth Syst Dynam. 2019;10:45-57.

64. Park J-Y, Stock CA, Dunne J, Yang X, Rosati A. Seasonal to multiannual marine ecosystem prediction with a global Earth system model. Science. 2019;365(6450):284-8. https://doi.org/10. 1126/science.aav6634.

65. Séférian R, Bopp L, Gehlen M, Swingedouw D, Mignot J, Guilyardi E, et al. Multiyear predictability of tropical marine productivity. Proc Natl Acad Sci. 2014;111(32):11646-51.

66. Séférian R, Berthet CSM. Assessing the decadal predictability of land and ocean carbon uptake. Geophys Res Lett. 2018;45:245566.

67. Yeager SG, Danabasoglu G, Rosenbloom NA, Strand W, Bates $\mathrm{SC}$, Meehl GA, et al. Predicting near-term changes in the Earth System: a large ensemble of initialized decadal prediction simulations using the Community Earth System Model. Bull Amer Meteor Soc. 2018;99:1867-86.
68. Peters GP, et al. Towards real-time verification of $\mathrm{CO} 2$ emissions. Nat Clim Chang. 2017;7:848-50. https://doi.org/10.1038/s41558017-0013-9.

69. Tommasi $\mathrm{D}$, et al. Managing living marine resources in a dynamic environment: the role of seasonal to decadal climate forecasts. Prog Oceanogr. 2017;152:15-49. https://doi.org/10.1016/j. pocean.2016.12.011.

70. Bakker DCE, et al. A multi-decade record of high-quality fCO2 data in version 3 of the Surface Ocean CO2 atlas (SOCAT). Earth Syst Sci Data. 2016;8:383-413. https://doi.org/10.5194/essd-8383-2016.

71. Buitenhuis ET, et al. MAREDAT: towards a world atlas of MARine Ecosystem DATa. Earth Syst Sci Data. 2013;5:22739. https://doi.org/10.5194/essd-5-227-2013.

72. Key RM, et al. Global Ocean Data Analysis Project, Version 2 (GLODAPv2). Ornl/Cdiac-162, Ndp-093. 2015;8:297-323. https://doi.org/10.3334/CDIAC/OTG.NDP093_GLODAPv2.

73. Wu T, Lu Y, Fang Y, Xin X, Li L, Li W, et al. The Beijing Climate Center Climate System Model (BCC-CSM): main progress from CMIP5 to CMIP6. Geosci Model Dev. 2019;12:1573-600.

74. Swart NC, Cole JNS, Kharin VV, Lazare M, Scinocca JF, Gillett NP, et al. The Canadian Earth System Model version 5 (CanESM5.0.3). Geosci Model Dev. 2019;12:4823-73. https:// doi.org/10.5194/gmd-12-4823-2019.

75. Danabasoglu G, Lamarque J-F, Bacmeister J, Bailey DA, DuVivier AK, Edwards J, et al. The Community Earth System Model Version 2 (CESM2). J Adv Model Earth Syst. 2020;12: e2019MS001916. https://doi.org/10.1029/2019MS001916.

76. Séférian R, Gehlen M, Bopp L, Resplandy L, Orr JC, Marti O, et al. Inconsistent strategies to spin up models in CMIP5: implications for ocean biogeochemical model performance assessment. Geosci Model Dev. 2016b;9:1827-51. https://doi.org/10.5194/ gmd-9-1827-2016.

77. Séférian R, Nabat P, Michou M, Saint-Martin D, Voldoire A, Colin J, et al. Evaluation of CNRM Earth-System model, CNRM-ESM2-1: role of Earth system processes in present-day and future climate. J Adv Model Earth Syst. 2019;11:4182-227. https://doi.org/10.1029/2019MS001791.

78. Held IM, Guo H, Adcroft A, Dunne JP, Horowitz LW, Krasting JP, et al. Structure and Performance of GFDL's CM4.0 Climate Model. J Adv Model Earth Syst. 2019;11(11). https://doi.org/10. 1029/2019MS001829.

79. Krasting JP, John JG, Blanton C, McHugh C, Nikonov S, Radhakrishnan A, et al. NOAA-GFDL GFDL-ESM4 model output prepared for CMIP6 CMIP. Earth System Grid Federation. 2018. https://doi.org/10.22033/ESGF/CMIP6.1407.

80. Ito G, Romanou A, Kiang NY, Faluvegi G, Aleinov I, Ruedy G, et al. Global carbon cycle and climate feedbacks in the NASA GISS ModelE2.1. Submitted to Journal of Advances in Modeling Earth Systems. in review.

81. Jones CD, Hughes JK, Bellouin N, Hardiman SC, Jones GS, Knight J, et al. The HadGEM2-ES implementation of CMIP5 centennial simulations. Geosci Model Dev. 2011;4:543-70. https://doi.org/10.5194/gmd-4-543-2011.

82. Sellar AA, Jones CG, Mulcahy J, Tang Y, Yool A, Wiltshire A, et al. UKESM1: description and evaluation of the UK Earth System Model. J Adv Model Earth Syst. 2019. https://doi.org/ 10.1029/2019MS0017392019.

83. Boucher O, Servonnat J, Albright AL, Aumont O, Balkanski Y, Bastrikov V et al. (2020) Presentation and evaluation of the IPSLCM6A-LR climate model. J Adv Model Earth Syst. in review

84. Hajima T, Watanabe M, Yamamoto A, Tatebe H, Noguchi MA, Abe M, et al. Description of the MIROC-ES2L Earth system model and evaluation of its climate-biogeochemical processes and feedback. Geosci Model Dev Discuss. 2019a. https://doi. org/10.5194/gmd-2019-275 in review. 
85. Mauritsen T, Bader J, Becker T, Behrens J, Bittner M, Brokopf R, et al. Developments in the MPI-M Earth System Model version 1.2 (MPI-ESM 1.2) and its response to increasing CO2. J Adv Model Earth Syst. 2019;11:998-1038. https://doi.org/10.1029/ 2018MS001400.

86. Yukimoto S, Adachi Y, Hosaka M, Sakami T, Yoshimura H, Hirabara M, et al. A new global climate model of the meteorological research institute: MRI-CGCM3 - model description and basic performance - J Meteor Soc Japan. 2012;90A:23-64. https:// doi.org/10.2151/jmsj.2012-A02.

87. Seland $\varnothing$, Bentsen M, Seland Graff L, Olivié D, Toniazzo T, Gjermundsen A, et al. The Norwegian Earth System Model, NorESM2 - evaluation of theCMIP6 DECK and historical simulations. Geosci Model Dev Discuss. 2020. https://doi.org/10.5194/ gmd-2019-378 in review.

88. Zahariev K, Christian JR, Denman KL. Preindustrial, historical, and fertilization simulations using a global ocean carbon model with new parameterizations of iron limitation, calcification, and N2 fixation. Prog Oceanogr. 2008;77:56-82.

89. Hayashida H, Christian JR, Holdsworth AM, Hu X, Monahan AH, Mortenson E, et al. CSIB v1 (Canadian Sea-ice Biogeochemistry): a sea-ice biogeochemical model for the NEMO community ocean modelling framework. Geosci Model Dev. 2019a;12:1965-90. https://doi.org/10.5194/gmd-12-19652019.

90. Moore JK, Doney SC, Lindsay K. Upper ocean ecosystem dynamics and iron cycling in a global three-dimensional model. Glob Biogeochem Cycles. 2004;18, GB4028. https://doi.org/10. 1029/2004GB002220.

91. Aumont O, Ethé C, Tagliabue A, Bopp L, Gehlen M. PISCES-v2: an ocean biogeochemical model for carbon and ecosystem studies. Geosci Model Dev. 2015;8:2465-513. https://doi.org/10.5194/ gmd-8-2465-2015.

92. Stock CA, Dunne JP, Fan S, Ginoux P, John J, Krasting JP, et al. Ocean biogeochemistry in GFDL's earth system model 4.1 and its response to increasing atmospheric CO2. J Adv Model Earth Syst. submitted, in review.

93. Dunne JP, Bociu I, Bronselaer B, Guo H, John JG, Krasting JP, et al. submitted-a Simple Global Ocean Biogeochemistry with Light, Iron, Nutrients and Gas version 2 (BLINGv2): model description and simulation characteristics in GFDL's CM4.0. J Adv Model Earth Syst. in review.

94. Dunne JP, Horowitz LW, Adcroft AJ, Ginoux P, Held IM, John JG, et al. The GFDL Earth System Model version 4.1 (GFDLESM4.1): model description and simulation characteristics. J Adv Model Earth Syst. submitted-b:2019MS002008.

95. Lerner P, Romanou A, Kelley M, Romanski J, Ruedy R, Russell G. Drivers of air-sea CO2 flux seasonality and its long-term changes in the NASA-GISS model CMIP6 submission. J Adv Model Earth Syst. in review.

96. Totterdell IJ. Description and evaluation of the Diat-HadOCC model v1.0: the ocean biogeochemical component of HadGEM2-ES. Geosci Model Dev. 2019a;12:4497-549. https:// doi.org/10.5194/gmd-12-4497-2019.

97. Yool A, Popova EE, Anderson TR. MEDUSA-2.0: an intermediate complexity biogeochemical model of the marine carbon cycle for climate change and ocean acidification studies. Geosci Model Dev. 2013;6:1767-811. https://doi.org/10.5194/gmd-6-17672013.

98. Hajima T, Kawamiya M, Watanabe M, et al. Modeling in Earth system science up to and beyond IPCC AR5. Prog. in Earth and Planet. Sci. 2014;1:29. https://doi.org/10.1186/s40645-014-0029y.

99. Paulsen H, Ilyina T, Six KD, Stemmler I. Incorporating a prognostic representation of marine nitrogen fixers into the global ocean biogeochemical model HAMOCC. J Adv Model Earth Syst. 2017;9:438-64. https://doi.org/10.1002/2016MS000737.

100. Nakano H, Tsujino H, Hirabara M, Yasuda T, Motoi T, Ishii M, et al. Uptake mechanism of anthropogenic $\mathrm{CO} 2$ in the Kuroshio Extension region in an ocean general circulation model. J Oceanogr. 2011;67:765-83. https://doi.org/10.1007/s10872-0110075-7.

101. Tjiputra JF, Roelandt C, Bentsen M, Lawrence DM, Lorentzen T, Schwinger J, et al. Evaluation of the carbon cycle components in the Norwegian Earth System Model (NorESM). Geosci Model Dev. 2013;6:301-25. https://doi.org/10.5194/gmd-6-301-2013.

102. Tjiputra JF, Schwinger J, Bentsen M, Morée AL, Gao S, Bethke I, et al. Ocean biogeochemistry in the Norwegian Earth System Model version 2 (NorESM2). Geosci Model Dev Discuss. 2020. https://doi.org/10.5194/gmd-2019-347 in review.

103. Griffies SM, Adcroft AJ, Banks H, Boning CW, Chassignet EP, Danabasoglu G, et al. Problems and prospects in large-scale ocean circulation models. In: Hall J, Harrison DE, Stammer D, editors. Proceedings of the OceanObs'09 Conference: Sustained Ocean Observations and Information for Society, 21-25 September 2009, Vol. 2. Venice: ESA Publication WPP; 2010. p. 306.

104. Tagliabue A, Völker C. Towards accounting for dissolved iron speciation in global ocean models. Biogeosciences. 2011;8: 3025-39. https://doi.org/10.5194/bg-8-3025-2011.

105. Galbraith ED, Dunne JP, Gnanadesikan A, Slater RD, Sarmiento JL, Dufour CO, et al. Complex functionality with minimal computation: promise and pitfalls of reduced-tracer ocean biogeochemistry models. J Adv Model Earth Syst. 2015;7:2012-28. https://doi.org/10.1002/2015MS000463.

106. Karl DM, Björkman KM, Dore JE, Fujieki L, Hebel DV, Houlihan T, et al. Ecological nitrogen-to-phosphorus stoichiometry at station ALOHA. Deep Sea Res Part II Top Stud Oceanogr. 2001;48:1529-66. https://doi.org/10.1016/S0967-0645(00) 00152-1.

107. Klausmeier CA, Litchman E, Daufresne T, Levin SA. Optimal nitrogen-to-phosphorus stoichiometry of phytoplankton. Nature. 2004;429:171-4. https://doi.org/10.1038/nature02454.

108. Kwiatkowski L, Aumont O, Bopp L, Ciais P. The impact of variable phytoplankton stoichiometry on projections of primary production, food quality, and carbon uptake in the Global Ocean. Glob Biogeochem Cycles. 2018;32:516-28. https://doi.org/10. 1002/2017GB005799.

109. Tanioka T, Matsumoto K. Buffering of ocean export production by flexible elemental stoichiometry of particulate organic matter. Glob Biogeochem Cycles. 2017;31:1528-42. https://doi.org/10. 1002/2017GB005670.

110. Weber TS, Deutsch C. Ocean nutrient ratios governed by plankton biogeography. Nature. 2010;467:550-4. https://doi.org/10.1038/ nature09403.

111. Ardyna M, et al. Hydrothermal vents trigger massive phytoplankton blooms in the Southern Ocean. Nat Commun. 2019;10:2451. https://doi.org/10.1038/s41467-019-09973-6.

112. Boyd PW, Ellwood MJ. The biogeochemical cycle of iron in the ocean. Nat Geosci. 2010;3:675-82. https://doi.org/10.1038/ ngeo964.

113. Death R, Wadham JL, Monteiro F, Le Brocq AM, Tranter M, Ridgwell A, et al. Antarctic ice sheet fertilises the Southern Ocean. Biogeosciences. 2014;11:2635-2643. https://doi.org/10. 5194/bg-11-2635-2014 https://www.biogeosciences.net/11/2635/ 2014/ (Accessed November 3, 2019).

114. Stibal M, Šabacká M, Žárský J. Biological processes on glacier and ice sheet surfaces. Nat Geosci. 2012;5:771-4. https://doi.org/ 10.1038 /ngeo1611.

115. Tagliabue A, et al. Hydrothermal contribution to the oceanic dissolved iron inventory. Nat Geosci. 2010;3:252-6. https://doi.org/ 10.1038/ngeo818. 
116. Tagliabue AO, Bopp L. The impact of different external sources of iron on the global carbon cycle. Geophys Res Lett. 2014;41:920 6. https://doi.org/10.1002/2013GL059059.

117. Tagliabue A, Aumont O, DeAth R, Dunne JP, Dutkiewicz S, Galbraith E, et al. How well do global ocean biogeochemistry models simulate dissolved iron distributions? Glob Biogeochem Cycles. 2016;30:149-74. https://doi.org/10.1002/ 2015GB005289

118. Liu S, Lu XX, Xia X, Zhang S, Ran L, Yang X, et al. Dynamic biogeochemical controls on river $\mathrm{pCO} 2$ and recent changes under aggravating river impoundment: an example of the subtropical Yangtze River. Glob Biogeochem Cycles. 2016;30:880-97. https://doi.org/10.1002/2016GB005388.

119. Liu J, Su N, Wang X, Du J. Submarine groundwater discharge and associated nutrient fluxes into the Southern Yellow Sea: a case study for semi-enclosed and oligotrophic seas-implication for green tide bloom. J Geophys Res Ocean. 2017;122:139-52. https://doi.org/10.1002/2016JC012282.

120. Moore WS, Sarmiento JL, Key RM. Submarine groundwater discharge revealed by 228Ra distribution in the upper Atlantic Ocean. Nat Geosci. 2008;1:309-11. https://doi.org/10.1038/ ngeo183.

121. Rodellas V, Garcia-Orellana J, Masqué P, Feldman M, Weinstein Y. Submarine groundwater discharge as a major source of nutrients to the Mediterranean Sea. Proc Natl Acad Sci. 2015;112: 3926-30. https://doi.org/10.1073/pnas.1419049112.

122. Schlosser C, et al. Seasonal ITCZ migration dynamically controls the location of the (sub) tropical Atlantic biogeochemical divide. Proc Natl Acad Sci. 2014;111:1438-42. https://doi.org/10.1073/ pnas.1318670111 http://www.pnas.org/cgi/doi/10.1073/pnas. 1318670111

123. Stefels J. Physiological aspects of the production and conversion of DMSP in marine algae and higher plants. J Sea Res. 2000;43: 183-97. https://doi.org/10.1016/S1385-1101(00)00030-7.

124. Sunda W, Kieber D, Kiene R, et al. An antioxidant function for DMSP and DMS in marine algae. Nature. 2002;418:317-20. https://doi.org/10.1038/nature00851.

125. Green TK, Hatton AD. The CLAW hypothesis: a new perspective on the role of biogenic sulphur in the regulation of global climate. Oceanogr Mar Biol. 2014;52:315-36. https://doi.org/10.1201/ b17143-7.

126. Brévière EHG, et al. Surface ocean-lower atmosphere study: scientific synthesis and contribution to Earth system science. Anthropocene. 2015;12:54-68. https://doi.org/10.1016/j.ancene. 2015.11.001.

127. Quinn PK, Bates TS. The case against climate regulation via oceanic phytoplankton sulphur emissions. Nature. 2011;480:51-6. https://doi.org/10.1038/nature10580.

128. Quinn PK, Coffman DJ, Johnson JE, Upchurch LM, Bates TS. Small fraction of marine cloud condensation nuclei made up of sea spray aerosol. Nat Geosci. 2017;10:674-9. https://doi.org/10. 1038/ngeo3003.

129. Galí M, Devred E, Levasseur M, Royer SJ, Babin M. A remote sensing algorithm for planktonic dimethylsulfoniopropionate (DMSP) and an analysis of global patterns. Remote Sens Environ. 2015;171:171-84. https://doi.org/10.1016/j.rse.2015.10. 012 .

130. Schwinger J, Tjiputra J, Goris N, Six KD, Kirkevåg A, Seland Ø, et al. Amplification of global warming through $\mathrm{pH}$ dependence of DMS production simulated with a fully coupled Earth system model. Biogeosciences. 2017;14:3633-48. https://doi.org/10. 5194/bg-14-3633-2017.

131. Six KD, Kloster S, Ilyina T, Archer SD, Zhang K, Maier-Reimer E. Global warming amplified by reduced sulphur fluxes as a result of ocean acidification. Nat Clim Chang. 2013;3:975-8. https://doi. org/10.1038/nclimate1981
132. Kirkby J, et al. Role of sulphuric acid, ammonia and galactic cosmic rays in atmospheric aerosol nucleation. Nature. 2011;476:429-33. https://doi.org/10.1038/nature10343.

133. Bianchi D, Dunne JP, Sarmiento JL, Galbraith ED. Data-based estimates of suboxia, denitrification, and $\mathrm{N} 2 \mathrm{O}$ production in the ocean and their sensitivities to dissolved O2. Glob Biogeochem Cycles. 2012;26:1-47. https://doi.org/10.1029/2011GB004209.

134. Buitenhuis ET, Suntharalingam P, Le Quéré C. Constraints on global oceanic emissions of $\mathrm{N} 2 \mathrm{O}$ from observations and models. Biogeosci Discuss. 2017:1-23. https://doi.org/10.5194/bg-2017193.

135. Jin X, Gruber N. Offsetting the radiative benefit of ocean iron fertilization by enhancing $\mathrm{N}_{2} \mathrm{O}$ emissions. Geophys Res Lett. 2003;30:1-4. https://doi.org/10.1029/2003GL018458.

136. Landolfi A, Somes CJ, Koeve W, Zamora LM, Oschlies A. Oceanic nitrogen cycling andN2O flux perturbations in the Anthropocene. Glob Biogeochem Cycles. 2017;31:1236-55. https://doi.org/10.1002/2017GB005633.

137. Martinez-Rey J, Bopp L, Gehlen M, Tagliabue A, Gruber N. Projections of oceanic $\mathrm{N} 2 \mathrm{O}$ emissions in the 21 st century using the IPSL Earth system model. Biogeosciences. 2015;12:4133-48. https://doi.org/10.5194/bg-12-4133-2015.

138. Nevison C, Butler JH, Elkins JW. Global distribution of $\mathrm{N}_{2} \mathrm{O}$ and the $\Delta \mathrm{N}_{2}$ O-AOU yield in the subsurface ocean. Glob Biogeochem Cycles. 2003. https://doi.org/10.1029/ 2003GB002068.

139. Hense I, Stemmler I, Sonntag S. Ideas and perspectives: climaterelevant marine biologically driven mechanisms in Earth system models. Biogeosciences. 2017;14:403-13. https://doi.org/10. 5194/bg-14-403-2017.

140. Kahru M, Leppanen J-M, Rud O. Cyanobacterial blooms cause heating of the sea surface. Mar Ecol Prog Ser. 1993;101:1-7. https://doi.org/10.3354/meps101001.

141. Hourdin F, et al. The art and science of climate model tuning. Bull Am Meteorol Soc. 2017;98:589-602. https://doi.org/10.1175/ BAMS-D-15-00135.1 http://journals.ametsoc.org/doi/10.1175/ BAMS-D-15-00135.1.

142. Jones CD, Arora V, Friedlingstein P, Bopp L, Brovkin V, Dunne J, et al. C4MIP - the Coupled Climate-Carbon Cycle Model Intercomparison Project: experimental protocol for CMIP6. Geosci Model Dev. 2016;9:2853-80. https://doi.org/10.5194/ gmd-9-2853-2016.

143. Landschützer P, Gruber N, Bakker DCE. Decadal variations and trends of the global ocean carbon sink. Glob Biogeochem Cycles. 2016;30:1396-417. https://doi.org/10.1002/2015GB005359.

144. Valente A, et al. A compilation of global bio-optical in situ data for ocean-colour satellite applications. Earth Syst Sci Data. 2016;8: 235-52. https://doi.org/10.5194/essd-8-235-2016.

145. Garcia, H.E.R.A., Locarnini, T. P, Boyer, J. I, Antonov, O.K. Baranova, M.M. Zweng, J.R. Reagan, D.R. Johnson, 2014 World Ocean Atlas 2013, Volume 3: Dissolved oxygen, apparent oxygen utilization, and oxygen saturation. S. Levitus, Ed., A. Mishonov Technical Ed.; NOAA Atlas NESDIS 75, 27 pp.

146. Gregg WW, Casey NW. Global and regional evaluation of the SeaWiFS chlorophyll data set. Remote Sens Environ. 2004;93: 463-79.

147. Johnson R, Strutton PG, Wright SW, McMinn A, Meiners KM. Three improved satellite chlorophyll algorithms for the Southern Ocean. J Geophys Res Oceans. 2013;118(7):3694-703. https:// doi.org/10.1002/jgrc.20270.

148. Laufkötter C, John JG, Stock CA, Dunne JP. Temperature and oxygen dependence of the remineralization of organic matter. Glob Biogeochem Cycles. 2017;31(7):1038-50. https://doi.org/ 10.1002/2017GB005643. 
149. Tagliabue A, Bowie A, Boyd P, et al. The integral role of iron in ocean biogeochemistry. Nature. 2017;543:51-9. https://doi.org/ 10.1038 /nature21058.

150. Martin JH. Glacial-interglacial CO2 change: the iron hypothesis. Paleoceanography. 1990;5(1):1-13. https://doi.org/10.1029/ PA005i001p00001.

151. Schneider B, Bopp L, Gehlen M, Segschneider J, Frölicher TL, Cadule $\mathrm{P}$, et al. Climate-induced interannual variability of marine primary and export production in three global coupled climate carbon cycle models. Biogeosciences. 2008;5:597-614. https:// doi.org/10.5194/bg-5-597-2008.

152. Dutkiewicz S, Follows MJ, Parekh P. Interactions of the iron and phosphorus cycles: a three-dimensional model study. Glob Biogeochem Cycles. 2005;19, GB1021. https://doi.org/10.1029/ 2004GB002342.

153. Moore JK, Braucher O. Sedimentary and mineral dust sources of dissolved iron to the world ocean. Biogeosciences. 2008;5:63156. https://doi.org/10.5194/bg-5-631-2008.

154. Völker C, Tagliabue A. Modeling organic iron-binding ligands in a three-dimensional biogeochemical ocean model. Mar Chem. 2015;173:67-77. https://doi.org/10.1016/J.MARCHEM.2014.11. 008 .

155. Le Quéré C, Andrew RM, Friedlingstein P, Sitch S, Hauck J, Pongratz J, et al. Global Carbon Budget 2018. Earth Syst. Sci. Data. 2018;10:2141-94. https://doi.org/10.5194/essd-10-21412018.

156. Resplandy L, Keeling RF, Rödenbeck C, Stephens BB, Khatiwala $\mathrm{S}$, Rodgers KB, et al. Revision of global carbon fluxes based on a reassessment of oceanic and riverine carbon transport. Nat Geosci. 2018;11:504-9. https://doi.org/10.1038/s41561-018-0151-3.

157. Behrenfeld MJ, Boss E, Siegel DA, Shea DM. Carbon-based ocean productivity and phytoplankton physiology from space. Glob Biogeochem Cycles. 2005;19:GB1006. https://doi.org/10. 1029/2004GB002299.

158. Kulk G, Platt T, Dingle J, Jackson T, Jönsson BF, Bouman HA, et al. Primary production, an index of climate change in the ocean: satellite-based estimates over two decades. Remote Sens. 2020;12: 826.

159. Dunne JP, Sarmiento JL, Gnanadesikan A. A synthesis of global particle export from the surface ocean and cycling through the ocean interior and on the seafloor. Glob Biogeochem Cycles. 2007;21(4). https://doi.org/10.1029/2006GB002907.

160. Tréguer PJ, De La Rocha CL. The World Ocean silica cycle. Annu Rev Mar Sci. 2013;(1):477-501.

161. Carr ME, Friedrichs MA, Schmeltz M, Noguchi Aita M, Antoine $\mathrm{D}$, Arrigo KR, et al. A comparison of global estimates of marine primary production from ocean color. Deep-Sea Res Part II Top Stud Oceanogr. 2006;53:741-70. https://doi.org/10.1016/j.dsr2. 2006.01.028.

162. de Boyer Montégut C, Madec G, Fischer AS, Lazar A, Iudicone D. Mixed layer depth over the global ocean: an examination of profile data and a profile-based climatology. J Geophys Res C Ocean. 2004;109:1-20. https://doi.org/10.1029/2004JC002378.

163. Kessler A, Tjiputra J. The Southern Ocean as a constraint to reduce uncertainty in future ocean carbon sinks. Earth Syst Dynam. 2016;7:295-312. https://doi.org/10.5194/esd-7-295-2016.

164. Berthet S, Séférian R, Bricaud C, Chevallier M, Voldoire A, Ethé C. Evaluation of an online grid-coarsening algorithm in a global eddy-admitting ocean biogeochemical model. J Adv Model Earth Syst. 2019;11:1759-83. https://doi.org/10.1029/2019MS001644.

165. Person R, Aumont O, Lévy M. The biological pump and seasonal variability of pCO 2 in the southern ocean: exploring the role of diatom adaptation to low Iron. J Geophys Res Ocean. 2018;123: 3204-26. https://doi.org/10.1029/2018JC013775.

166. Tittensor DP, et al. Integrating climate adaptation and biodiversity conservation in the global protected ocean. Sci Adv. 2019;5:In revision:eaay9969. https://doi.org/10.1126/sciadv.aay9969.

167. Ward BA, et al. Considering the role of adaptive evolution in models of the ocean and climate system. J Adv Model Earth Syst. 2019. https://doi.org/10.1029/2018MS001452.

168. Henson S, Beaulieu C, Ilyina T, et al. Rapid emergence of climate change in environmental drivers of marine ecosystems. Nat Commun. 2017;8:14682. https://doi.org/10.1038/ncomms14682.

169. Schlitzer R, et al. The GEOTRACES Intermediate Data Product 2017. Chem Geol. 2018;493:210-23. https://doi.org/10.1016/j. chemgeo.2018.05.040.

170. Tagliabue A, Bowie AR, DeVries T, Ellwood MJ, Landing WM, Milne A, et al. The interplay between regeneration and scavenging fluxes drives ocean iron cycling. Nat Commun. 2019;10:4960. https://doi.org/10.1038/s41467-019-12775-5.

171. Tagliabue A, Hawco NJ, Bundy RM, Landing WM, Milne A, Morton PL, et al. The role of external inputs and internal cycling in shaping the global ocean cobalt distribution: insights from the first cobalt biogeochemical model. Glob Biogeochem Cycles. 2018;32:594-616. https://doi.org/10.1002/2017GB005830.

172. Weber T, John S, Tagliabue A, DeVries T. Biological uptake and reversible scavenging of zinc in the global ocean. Science (80-). 2018;361:72 LP-76. https://doi.org/10.1126/science.aap8532.

173. van Hulten M, Middag R, Dutay J-C, de Baar H, Roy-Barman M, Gehlen M, et al. Manganese in the west Atlantic Ocean in the context of the first global ocean circulation model of manganese. Biogeosciences. 2017;14:1123-52. https://doi.org/10.5194/bg14-1123-2017.

174. Richon C, Tagliabue A. Insights into the major processes driving the global distribution of copper in the ocean from a global model. Glob Biogeochem Cycles. 2019;33:1594-610. https://doi.org/10. 1029/2019GB006280.

175. Ward BA, Follows MJ. Marine mixotrophy increases trophic transfer efficiency, mean organism size, and vertical carbon flux. PNAS. 2016;113:2958-63. https://doi.org/10.1073/pnas. 1517118113.

176. Lana A, Bell TG, Simó R, Vallina SM, Ballabrera-Poy J, Kettle AJ, et al. An updated climatology of surface dimethlysulfide concentrations and emission fluxes in the global ocean. Glob Biogeochem Cycles. 2011;25:GB1004. https://doi.org/10.1029/ 2010GB003850

177. Buitenhuis ET, Suntharalingam P, Le Quéré C. Constraints on global oceanic emissions of $\mathrm{N} 2 \mathrm{O}$ from observations and models. Biogeosciences. 2018;15:2161-2175. https://doi.org/10.5194/bg15-2161-2018

178. Paulot F, Jacob DJ, Johnson MT, Bell TG, Baker AR, Keene WC, et al. Global oceanic emission of ammonia: constraints from seawater and atmospheric observations. Glob Biogeochem Cycles. 2015;29:1165-78. https://doi.org/10.1002/2015GB005106.

179. Kwiatkowski L, et al. iMarNet: an ocean biogeochemistry model intercomparison project within a common physical ocean modelling framework. Biogeosciences. 2014;11:7291-304. https://doi. org/10.5194/bg-11-7291-2014.

Publisher's Note Springer Nature remains neutral with regard to jurisdictional claims in published maps and institutional affiliations. 